\title{
ESTUDO DOS EFEITOS VASCULARES SECUNDÁRIOS À PRESENÇA DE PERIODONTITE EM RATOS
}

Tese apresentada ao Programa de Pós-Graduação em Farmacologia do Instituto de Ciências Biomédicas da Universidade de São Paulo, para a obtenção do Título de Doutor em Ciências. 
PAULA CAMPI LOCATELLI DE ALMEIDA

\section{ESTUDO DOS EFEITOS VASCULARES SECUNDÁRIOS À PRESENÇA DE PERIODONTITE EM RATOS}

Tese apresentada ao Programa de Pós-Graduação em Farmacologia do Instituto de Ciências Biomédicas da Universidade de São Paulo, para a obtenção do Título de Doutor em Ciências.

Área de concentração: Farmacologia

Orientador: Prof. Dr. Marcelo Nicolás Muscará

Versão original 
DADOS DE CATALOGAÇÃO NA PUBLICAÇÃO (CIP)

Serviço de Biblioteca e Informação Biomédica do Instituto de Ciências Biomédicas da Universidade de São Paulo

reprodução não autorizada pelo autor

Almeida, Paula Campi Locatelli de.

Estudo dos efeitos vasculares secundários à presença de periodontite em ratos / Paula Campi Locatelli de Almeida. -- São Paulo, 2012.

Orientador: Prof. Dr. Marcelo Nicolas Muscará.

Tese (Doutorado) - Universidade de São Paulo. Instituto de Ciências Biomédicas. Departamento de Farmacologia. Área de concentração: Farmacologia. Linha de pesquisa: Efeitos à distância mediados pela periodontite.

Versão do título para o inglês: Study of the vascular effects secondary to the presence of periodontitis in rats.

1. Periodontite 2. Prostaglandinas 3. Óxido nítrico 4. Acetilcolina 5. Aorta I. Muscará, Prof. Dr. Marcelo Nicolas II. Universidade de São Paulo. Instituto de Ciências Biomédicas. Programa de Pós-Graduação em Farmacologia III. Título. 
Candidato(a): $\quad$ Paula Campi Locatelli de Almeida.

Título da Tese: $\quad$ Estudo dos efeitos vasculares secundários à presença de periodontite em ratos.

Orientador(a): $\quad$ Prof. Dr. Marcelo Nicolas Muscará.

A Comissão Julgadora dos trabalhos de Defesa da Tese de Doutorado, em sessão pública realizada a considerou
( ) Aprovado(a)
( ) Reprovado(a)

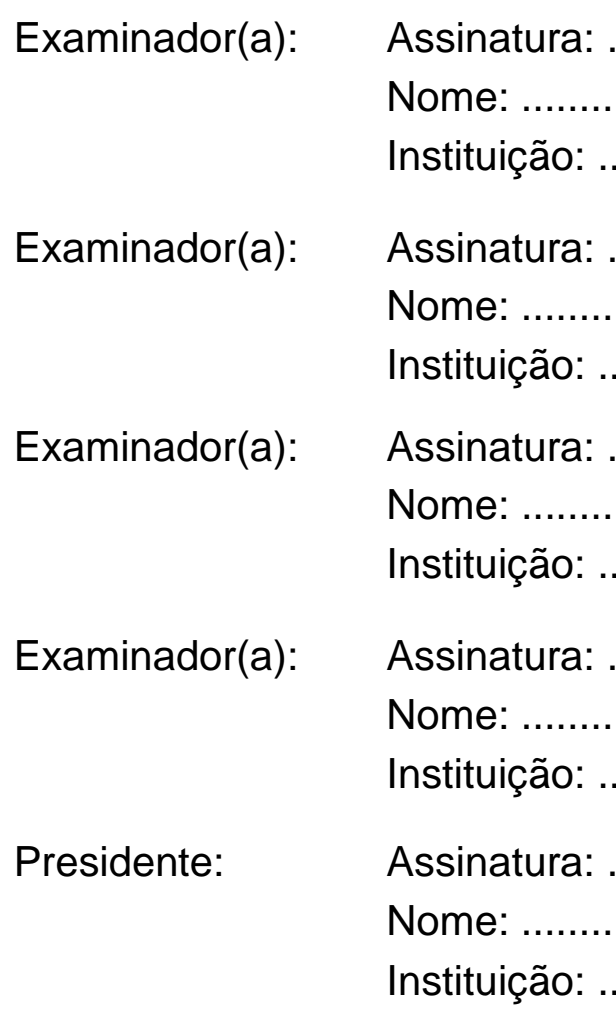




\section{Certificado}

Certificamos que o protocolo registrado sob $\mathrm{n}^{\circ} \mathbf{0 7 8}$ nas fls. 32 do livro 2 para uso de animais em experimentação, sob a responsabilidade de Marcelo Nicolás Muscará, Coordenador(a) da Linha de Pesquisa "Avaliação da influência da doença periodontal sobre a artrite de articulação temporomandibular de ratos" do qual participou(aram) o(s) alunos Paula Campi Locatelli de Almeida, Alexandre Danadai Souza, Aila Mirtes Teles, Aline Maia Dantas, Rodrigo Martins Porto, Bruno Schnneider Herrera, Ana Alice dos Santos Dias, Ana Augusta Varriano, Simone Marques Bolonnheis, Carly de Faria Coelho, Cristian César Carrari, Lidia Mitiko Yshii, Lívia de Lucca Camargo, Juliano Fernandes de Oliveira, Juliana Florenzano, Ligia de Cássia Val, Rodrigo Labat Marcos, Luciano Ramos, Livia Pimentel e os pesquisadores Soraia Katia P.Costa, Rodrigo Álvaro B.L.Martins, está de acordo com os Princípios Éticos de Experimentação Animal adotado pelo Colégio Brasileiro de Experimentação Animal (COBEA) e foi aprovado pela COMISSÃO DE ÉTICA EM EXPERIMENTAÇÃO ANIMAL (CEEA) em 26.05.2006.

São Paulo, 26 de maio de 2006.

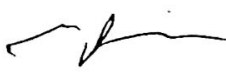

Profa. Dra. Marília C.L.Seelaender Coordenadora -CEEA - ICB/USP

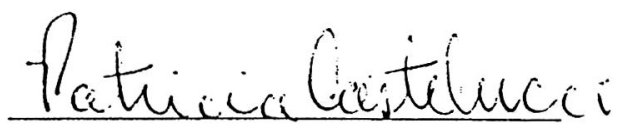

Profa. Dra. Patricia Castelucci Secretária Suplente CEEA - ICB/USP 


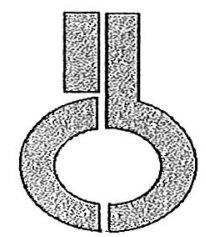

\section{UNIVERSIDADE DE SÃO PAULO INSTITUTO DE CIÊNCIAS BIOMÉDICAS}

Cidade Universitária "Armando de Salles Oliveira"

Av. Prof. Lineu Prestes, 2415 - CEP. 05508-000 São Paulo, SP - Brasil

Telefone :(55) (011) 3091-7733 - telefax : (55) (011) 3091-7438

e-mail: cep@icb.usp.br

\section{CER'TIFICADO}

Certificamos que o Protocolo para uso de animais em experimentação $\mathrm{n}^{\circ}$ 058/03, sobre o projeto intitulado "Avaliação do papel do óxido nítrico e espécies relacionadas na doença periodontal em ratos", sob a responsabilidade de Marcelo Nicolás Muscará, está de acordo com os Princípios Éticos na Experimentação Animal adotado pelo Colégio Brasileiro de Experimentação Animal (COBEA) e foi aprovado pela COMISSÃO DE ÉTICA EM EXPERIMENTAÇÃO ANIMAL (CEEA) em reunião de $25 / 08 / 2003$.

(We certify that the protocol $\mathrm{n}^{\circ} \mathbf{0 5 8 / 0 3}$, about "Role of nitric oxide and related species on periodontal disease in rats" agrees with the ETHICAL PRINCIPLES IN ANIMAL RESEARCH adopted by Brazilian College of Animal Experimentation (COBEA) and was approved by the BIOMEDICAL SCIENCES INSTITUTE/USP- ETHICAL COMMIT'TEE FOR ANIMAL RESEARCH (CEEA) in 25/08/2003 meeting.)

São Paulo, 27 de agosto de 2003.
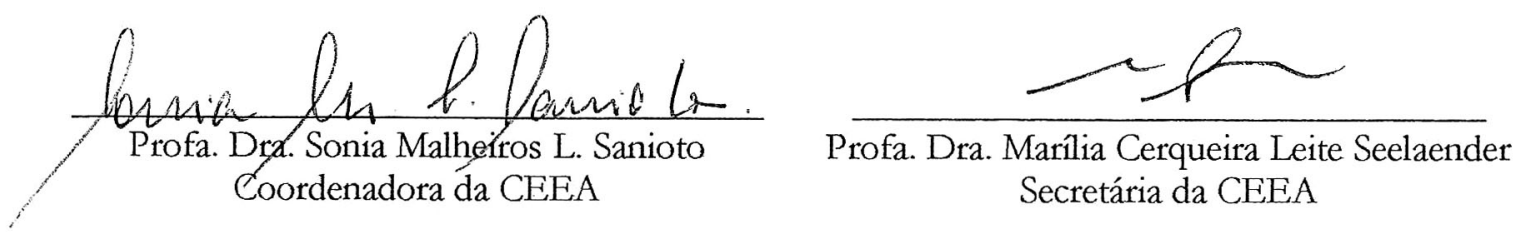
Aos meus pais, por me darem a formação educacional e emocional para que eu atingisse este objetivo tão sonhado. À minha irmã Carla, mesmo de longe, sempre por perto.

Ao meu marido Rogério por todo o apoio, companheirismo e encorajamento.

À minha amada filha Flávia, que alegra a minha existência e me dá forças para me superar a cada dia. 


\section{AGRADECIMENTOS}

Ao Prof. Dr. Marcelo Nicolás Muscará pela orientação, apoio, dedicação e amizade. À Prof. Dra. Soraia Kátia Pereira Costa pelo apoio e todo auxílio.

Ao grupo de periodontite do Laboratório de Farmacologia dos Radicais Livres: Dr. Bruno Schneider Herrera, Dr. Rodrigo Martins Porto e especialmente à Dra. Aline Maia Dantas que sobretudo é uma grande amiga que eu levo para a vida.

À Dra. Simone Aparecida Teixeira, sempre disposta a auxiliar e compartilhar conhecimento.

À querida amiga Cristiane Isabel Silva Mangialardo Ramos por todo auxílio e compreensão.

À mestranda Flávia Neto Jesus pelo auxilio dado nesta reta final;

A todos os demais, e não menos importantes, alunos do Laboratório de Farmacologia dos Radicais Livres por serem excelentes companheiros de trabalho e também pelo auxílio durante a execução do projeto.

Às queridas técnicas Maria Alice Barreto e Irene Maria Gouvêa por estarem sempre dispostas a ajudar.

À Prof. Dra. Eliana Akamine e à Prof. Dra. Graziela Ceravollo por todo auxílio nos experimentos de reatividade vascular.

Ao CNPq e à FAPESP pelo auxílio financeiro. 
"Só se pode alcançar um grande êxito quando nos mantemos fiéis a nós mesmos."

Friedrich Nietzsche 


\section{RESUMO}

CAMPI, P. Estudo dos efeitos vasculares secundários à presença de periodontite em ratos. 2012. $63 \mathrm{f}$. Tese (Doutorado em Farmacologia) - Instituto de Ciências Biomédicas, Universidade de São Paulo, São Paulo, 2012.

A destruição crônica do aparelho de inserção periodontal devido a uma intensa resposta inflamatória a bactérias conduz a uma condição clínica conhecida como doença periodontal. A inflamação periodontal geralmente provoca úlceras superficiais no sulco gengival, onde os capilares sanguíneos estão expostos a bactérias. Patógenos periodontais, assim como seus produtos podem ser translocados e liberados do sulco gengival para a corrente sanguínea e, portanto, ter efeitos periféricos. A bolsa periodontal é também importante reservatório de mediadores inflamatórios que podem atingir a corrente sanguínea. Diversos estudos avaliam a relação entre a doença periodontal e as doenças cardiovasculares. Sabese que muitas doenças cardiovasculares têm início em desordens vasculares, principalmente na camada endotelial dos vasos sanguíneos de grande condutância. Assim, o foco deste estudo foi investigar a reatividade vascular de aortas de animais com periodontite. Tanto a contração para a norepinefrina quanto o relaxamento para a acetilcolina estão diminuídos em animais com periodontite, mas os mecanismos para estes efeitos são diferentes. A diminuição da resposta contrátil à norepinefrina parece estar associada a um aumento da produção de óxido nítrico através da isoforma induzível da óxido nítrico sintase e a diminuição da resposta relaxante à acetilcolina parece estar associada a produção de prostanóides principalmente derivados da isoforma do tipo II da enzima ciclooxigenase.

Palavras-chave: Periodontite. Óxido Nítrico. Prostaglandinas. Norepinefrina. Acetilcolina. 


\begin{abstract}
CAMPI, P. Study of the vascular effects secondary to the presence of periodontitis in rats. 2012. 62 p. Ph. D. thesis (Pharmacology) - Instituto de Ciências Biomédicas, Universidade de São Paulo, São Paulo, 2012.

The chronic destruction of the periodontal attachment apparatus due to an intense inflammatory response to bacteria leads to a condition known as periodontal disease. The periodontal inflammation usually causes superficial ulcers in the gingival sulcus, where blood capillaries are exposed to bacteria. Periodontal pathogens, as well as their products can be translocated and released into the gingival sulcus, subsequently into the bloodstream and thus have peripheral effects. The periodontal pocket is also an important reservoir of inflammatory mediators that can reach the bloodstream. Several studies have evaluated the relationship between periodontal disease and cardiovascular disease. It is known that many cardiac diseases begin as vascular disorders, especially in the endothelial layer of blood vessels of large conductance. Thus, the focus of this study was to investigate the vascular reactivity of aortas from animals with periodontitis. Both norepinephrine-mediated contraction and acetylcholine-mediated relaxation are decreased in animals with periodontitis, but the mechanisms are different for these responsess. The contraction appears to be associated with increased production of nitric oxide by inducible isoform of nitric oxide synthase and relaxation with prostanoids primarily derived type II isoform of the enzyme cyclooxygenase.
\end{abstract}

Keywords: Periodontitis. Nitric Oxide. Prostaglandins. Norepinephrine. Acetylcholine. 


\section{LISTA DE ILUSTRAÇÕES}

Quadro 1 - Sequências especificas dos primers utilizados nos experimentos de PCR em

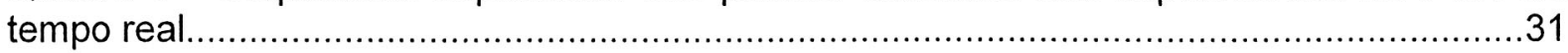
Figura 1 - Efeito da periodontite sobre a contração dos anéis de aorta de rato com $(E+)$ ou sem $(E-)$ endotélio em resposta à norepinefrina..................................................... 37 Figura 2 - Efeito da periodontite sobre a dilatação de anéis de aorta de rato em resposta à acetilcolina

Figura 3 - Efeito do tratamento in vitro com L-NAME (LN) sobre a resposta pressora à norepinefrina em anéis de aorta de animais sham ou periodontite. 38 Figura 4 - Efeito do tratamento in vitro com 1400W sobre a resposta pressora à norepinefrina em anéis de aorta de animais sham ou periodontite.................................39 Figura 5 - Efeito do tratamento in vitro com Indometacina (Indo) sobre a resposta pressora à norepinefrina em anéis de aorta de animais sham ou periodontite ..................................39 Figura 6 - Efeito do tratamento in vitro com SC560 sobre a resposta pressora para norepinefrina em anéis de aorta de animais sham ou periodontite.....................................40 Figura 7 - Efeito do tratamento in vitro com NS398 sobre a resposta pressora para norepinefrina em anéis de aorta de animais sham ou periodontite..................................40 Figura 8 - Efeito do tratamento in vitro com L-NAME (LN) sobre a dilatação de anéis de aorta de animais sham ou com periodontite, em resposta a acetilcolina. . .41 Figura 9 - Efeito do tratamento in vitro com 1400W sobre a dilatação de anéis de aorta de animais sham ou com periodontite, em resposta a acetilcolina........................................41 Figura 10 - Efeito do tratamento in vitro com Indometacina (Indo) sobre a dilatação de anéis de aorta de animais sham ou com periodontite, em resposta a acetilcolina........................42 Figura 11 - Efeito do tratamento in vitro com SC560 sobre a dilatação de anéis de aorta de animais sham ou com periodontite, em resposta a acetilcolina...................................42 Figura 12 - Efeito do tratamento in vitro com NS398 sobre a dilatação de anéis de aorta de animais sham ou com periodontite, em resposta a acetilcolina .........................................43 Figura 13 - Efeito do tratamento in vivo com L-NAME (LN) sobre a contração de anéis de aorta de animais sham ou com periodontite, em resposta à norepinefrina.........................44 Figura 14 - Efeito do tratamento in vivo com Etoricoxib (Eto) sobre a contração de anéis de aorta de animais sham ou com periodontite, em resposta à norepinefrina...........................45 Figura 15 - Efeito do tratamento in vivo com L-NAME (LN) sobre a dilatação dos anéis de aorta de animais sham ou com periodontite periodontite em resposta a acetilcolina...........46 Figura 16 - Efeito do tratamento in vivo com Etoricoxib (Eto) sobre a dilatação dos anéis de aorta de animais sham ou com periodontite periodontite em resposta a acetilcolina............46 Figura 17 - Efeito da adição de $84 \mathrm{mM}$ de $\mathrm{KCl}$ sobre aorta de animais sham ou com periodontite tratados com L-NAME (LN) ou Etoricoxib (Eto) com ou sem endotélio.............47 Figura 18 - Efeito do tratamento com L-NAME ou Etoricoxib sobre a pressão arterial (PA) de ratos com ou sem periodontite. .48

Figura 19 - Efeito da indução de periodontite e tratamento com L-NAME ou Etoricoxib sobre a expressão de mRNA para COX-1 em amostras de aorta de rato...................................49 Figura 20 - Efeito da indução de periodontite e tratamento com L-NAME ou Etoricoxib sobre a expressão de mRNA para COX-2 em amostras de aorta de rato.................................50 Figura 21 - Efeito da indução de periodontite e tratamento com L-NAME ou Etoricoxib sobre a expressão de mRNA para eNOS em amostras de aorta de rato.................................51 Figura 22 - Efeito da indução de periodontite e tratamento com L-NAME ou Etoricoxib sobre a expressão de mRNA para iNOS em amostras de aorta de rato........................................52 Figura 23 - Expressão proteica de COX-2 protein em amostras de aorta de animais com periodontite e sham 


\section{SUMÁRIO}

1 INTRODUÇÃO

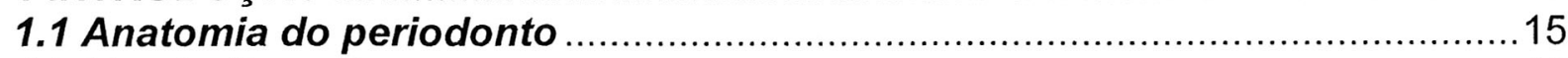

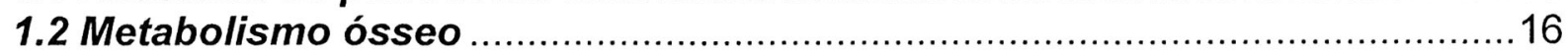

1.2.1 Fator de Estimulação de Colônias de Macrófagos ..........................................16

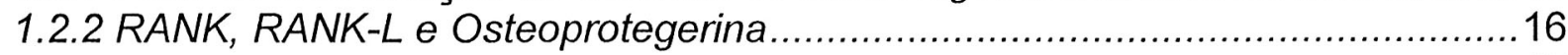

1.3 Alterações patológicas dos tecidos periodontais .....................................17

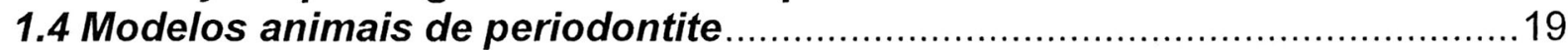

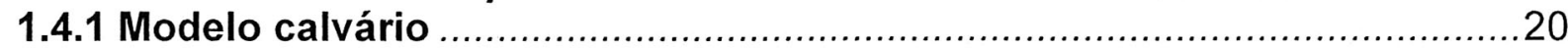

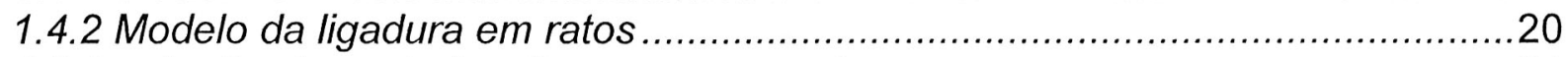

1.5 A relação da periodontite com outras doenças............................................21

1.6 Alterações vasculares mediadas pela periodontite ..................................23

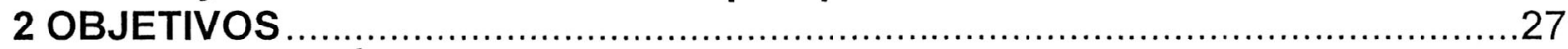

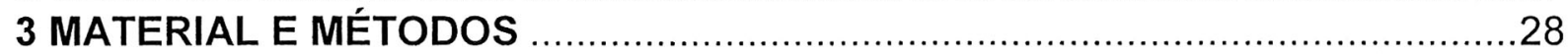

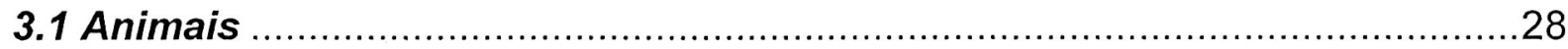

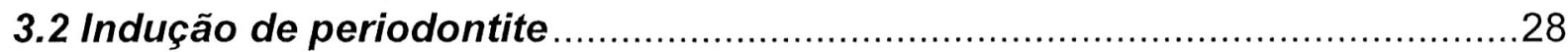

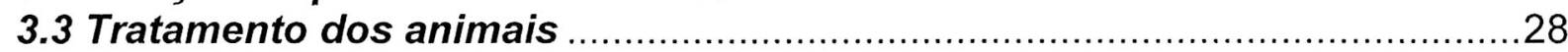

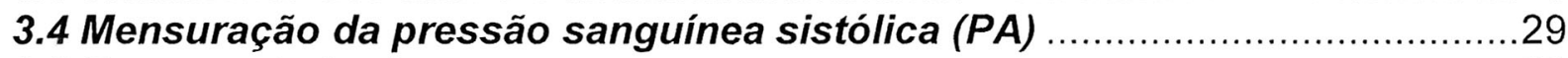

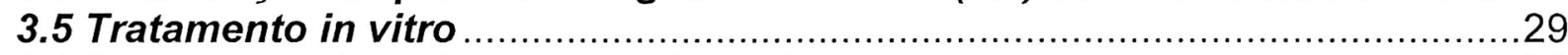

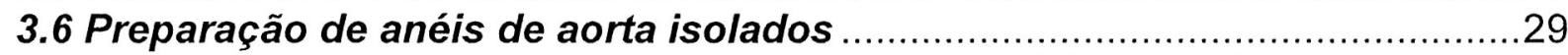

3.7 Análise de expressão gênica pela reação em cadeia da polimerase em tempo real (RT-PCR) ......................................................................... 30

3.8 Análise da expressão de resíduos protéicos de COX-2 e NOS endotelial

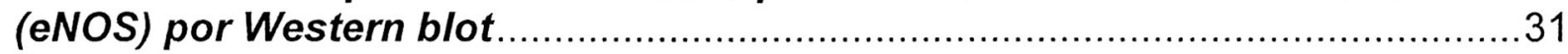

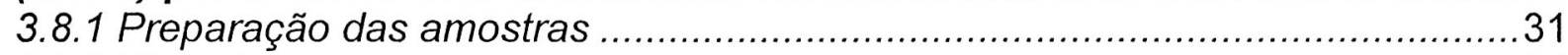

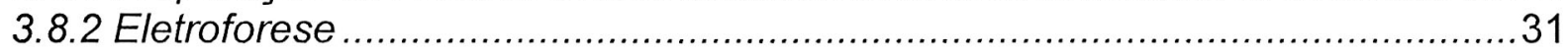

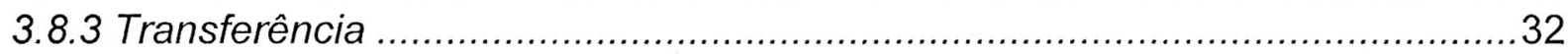

3.8.4 Bloqueio de sítios inespecificos e incubação com os anticorpos .....................32

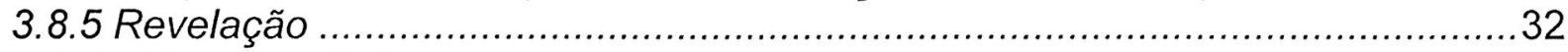

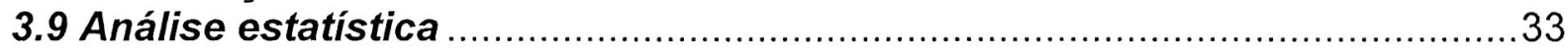

4 RESULTADOS

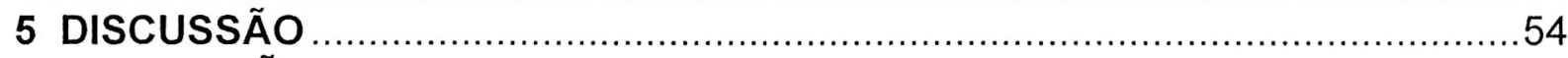

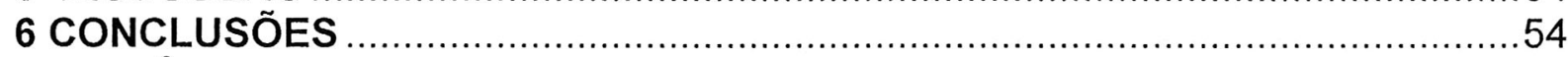

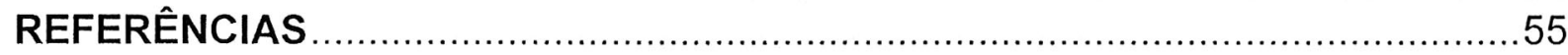




\section{INTRODUÇÃO}

A inflamação é uma resposta adaptativa desencadeada por estímulos nocivos tais como infecções e dano tecidual que visa restaurar a homeostase (MEDZHITOV, 2008). A resposta inflamatória aguda envolve o influxo coordenado de componentes sanguíneos (plasma e leucócitos) ao local afetado. O reconhecimento inicial da infecção é mediado por mastócitos e macrófagos residentes, levando a uma produção de diversos mediadores inflamatórios, entre eles, quimiocinas, citocinas, aminas vasoativas, eicosanóides e produtos de cascatas proteolíticas.

O efeito mais imediato e principal é a formação de um exsudato inflamatório local: proteínas plasmáticas e leucócitos (em sua maioria neutrófilos) normalmente restritos aos vasos sanguíneos, agora ganham acesso aos tecidos extravasculares, através de vênulas pós-capilares. O endotélio ativado destes vasos permite extravasamento seletivo de neutrófilos, prevenindo a saída de eritrócitos. Esta seletividade é devida à ligação induzivel de selectinas das células endoteliais com integrinas e receptores de quimiocinas em leucócitos, que ocorre na superfície endotelial, bem como nos espaços extravasculares (BONFANTI et al., 1989). Ao atingir os tecidos, os neutrófilos tornam-se ativados, seja por contato direto com os tecidos ou por ação de citocinas.

Dois tipos de eventos vasculares ocorrem na inflamação aguda: alterações de fluxo e calibre e alterações da permeabilidade. As alterações de fluxo e calibre são de grande importância no desenvolvimento da inflamação aguda por determinar a quantidade de influxo de fluido rico em plasma (conhecido como exsudato) a ser extravasado. Se o fluxo sanguíneo local for diminuído ou abolido, o mesmo ocorrerá com o exsudato. Ambos os efeitos são regulados pelo endotélio.

A ativação das células endoteliais na inflamação divide-se em respostas rápidas, independentes de expressão gênica (tipo I) e respostas mais lentas (tipo II) que dependem de expressão gênica (POBER; COTRAN, 1990). Em ambos os casos, existem três principais componentes responsáveis pelos quatro sinais cardinais da inflamação: um aumento do fluxo sanguíneo local, causando rubor e calor dos tecidos inflamados, aumento do exsudato, responsável pelo edema e um recrutamento e ativação de leucócitos circulantes para os tecidos danificados. A dor, o quarto sinal, é causada por mediadores liberados por leucócitos em fibras sensoriais do tipo $\mathrm{C}$ e $\mathrm{A} \delta$. 
Em tecidos não inflamados, as células endoteliais vasculares mantém a fluidez sanguínea através de mecanismos que inibem a coagulação intra-vascular, regulam o fluxo sanguíneo, controlam a permeabilidade vascular, inibem a ativação de leucócitos circulantes e a adesão ao endotélio (POBER; SESSA, 2007). Quando em seu estado basal, as células endoteliais bloqueiam as ações do fator VIla, glicoproteína cuja ativação depende de fatores extrínsecos como lesão tecidual e culmina com a conversão de pró-trombina a trombina, enzima que converte fibrinogênio em fibrina. Estas células também sintetizam e expressam proteoglicanos de heparam sulfato em sua superfície celular, os quais possuem propriedades anticoagulantes ativando antitrombina. Sintetizam e expressam também trombomodulina a qual, ligando-se à trombina, altera a sua especificidade de substrato, e esta deixa de clivar fibrinogênio e passa à clivagem e ativação de proteína $\mathrm{C}$, a qual destrói fatores de coagulação.

Além disso, as células endoteliais inibem a adesão e agregação plaquetária através da produção de óxido nítrico (NO) e prostaciclina ( $\mathrm{PGI}_{2}$ ) (SESSA, 2004). O fluxo sanguíneo é regulado por um equilibrio de sinais que aumentam ou diminuem o tônus das camadas circundantes de células musculares lisas (BUSSE; FLEMING, 2004). As proteínas plasmáticas são impedidas de atingir os tecidos extravasculares pela camada endotelial dos capilares. A estrutura das células endoteliais capilares varia de acordo com sua localização anatômica. Em capilares contínuos, as junções entre as células endoteliais adjacentes são do tipo "tight" e aderinas, compostas pela mesma família de proteínas que formam estruturas juncionais em células epiteliais.

Em situações normais, células endoteliais não interagem com leucócitos (LEY; REUTERSHAN, 2006). Isso ocorre porque elas internalizam proteínas que interagem com leucócitos, tais como P-selectina e quimiocinas e suprimem a transcrição de outras moléculas de adesão tais como E-selectina, molécula de adesão vascular tipo 1 (VCAM1). A produção basal de NO contribui para a quiescência do endotélio através da inibição de expressão gênica de mediadores pró-inflamatórios (DE CATERINA et al., 1995).

A falha em qualquer um destes mecanismos constitui uma disfunção endotelial. Este termo é mais utilizado para descrever uma queda de produção de NO, levando a um aumento da contração vascular, bem como ativação de leucócitos e plaquetas. 
A diminuição da produção de NO explica porque regiões com fluxo alterado, tais como pontos arteriais são particularmente susceptíveis a desenvolver ateromas, uma lesão crônica na parede arterial (HANSSON; LIBBY, 2006).

\subsection{Anatomia do periodonto}

A erupção dentária através da mucosa leva à formação de um ambiente único na interface entre a superfície mineralizada do dente e os tecidos moles adjacentes (NEWMAN, 1999). O periodonto, um complexo definido como os tecidos que sustentam, protegem e nutrem os dentes, compreende o cemento, ligamento periodontal, osso alveolar e a porção gengival em contato com o dente (junção dentogengival) (NANCI ; BOSSHARDT, 2006).

A junção dentogengival, é uma adaptação da mucosa oral que compreende componentes teciduais epiteliais e conjuntivos. O epitélio juncional tem um papel crucial já que este sela os tecidos periodontais do ambiente oral. Dessa forma, a sua integridade é essencial para manter a saúde periodontal. A doença periodontal instala-se quando, devido à ação de bactérias, a estrutura do epitélio juncional tornase falha. A camada celular em contato com o dente provê a conexão entre a gengiva e a superfície dental através de um complexo estrutural denominado ligamento epitelial. Ela contém espaços preenchidos por fluido gengival, que normalmente abrigam leucócitos polimorfonucleares e monócitos, que passam do tecido conjuntivo subepitelial através do epitélio juncional e para o sulco gengival, e assim constitui a primeira barreira imunológica contra o perpétuo desafio microbiano presente.

O tecido conjuntivo que suporta o epitélio juncional é diferente estruturalmente daquele que sustenta o epitélio oral gengival. Mesmo sob circunstâncias clínicas normais, ele apresenta um infiltrado de células inflamatórias. O tecido gengival conjuntivo adjacente ao epitélio juncional contem um plexo vascular complexo. Células inflamatórias como leucócitos polimorfonucleares e linfócitos-T extravasam continuamente desta rede de vênulas capilares e pós-capilares e migram através do epitélio juncional para o sulco gengival e eventualmente para o fluido oral. 
O cemento é o tecido conjuntivo duro e avascular que reveste as raízes dos dentes e serve primariamente para aderir às principais fibras do ligamento periodontal.

A maior parte do ligamento periodontal é formada pelo tecido conjuntivo liso especializado situado entre o cemento e o osso que forma o espaço preenchido pelo dente, o alvéolo (ligamento alvéolo dental). É um tecido conjuntivo particularmente adaptado à sua principal função, que é a de sustentar os dentes em seus alvéolos e ao mesmo tempo permitir que eles suportem as consideráveis forças de mastigação. Os tipos de colágeno predominantes no ligamento periodontal são os tipos I, III e XII.

O osso alveolar encontra-se em constante remodelamento, regulado principalmente por células responsáveis pela reabsorção óssea, os osteoclastos, e células responsáveis pela aposição óssea, os osteoblastos.

\subsection{Metabolismo ósseo}

Osteoclastos são células multinucleadas derivadas da linhagem monócito/macrófago e consideradas as principais células responsáveis pela reabsorção óssea (BOYLE; SIMONET; LACEY, 2003).

\subsubsection{Fator de Estimulação de Colônias de Macrófagos}

O fator de estimulação de colônias de macrófagos (M-SCF) é produzido principalmente por osteoblastos ou células do estroma da medula óssea e liga-se a um receptor de células precursoras de osteoclastos (cFMS), um membro da superfamília de receptores tirosina quinase. A ligação de M-CSF a cFMS resulta na ativação de diversos fatores de transcrição, incluindo c-fos, que leva ao início da osteoclastogênese. Aparentemente o papel principal da M-CSF é promover a proliferação e sobrevivência de pré-osteoclastos, bem como osteoclastos maduros (TAUBMAN et al., 2005).

\subsubsection{RANK, RANK-L e Osteoprotegerina}

O balanço entre a reabsorção pelos osteoclastos e a formação óssea por osteoblastos é finamente regulada pela produção de um receptor ativador do ligante 
de fator-KB (RANK-L). É uma proteína ligada à membrana, membro da super família do fator de necrose tumoral, expressa principalmente em osteoblastos, podendo ser expressa em células $T$ ativadas e fibroblastos. Sua expressão é regulada por moduladores do metabolismo ósseo tais como paratormônio e vitamina $D_{3}$ (MATSUZAKI et al., 1998).

A ligação de RANK-L ao seu receptor RANK na superfície de pré-osteoblastos resulta na ativação fator nuclear kappa $B$ (NF-kB) levando à formação de osteoclastos. A produção de RANKL é regulada por citocinas pró-inflamatórias, tais como fator de necrose tumoral alfa (TNF- $\alpha$ ) e interleucina (IL)-1 $\beta$ (HOFBAUER; HEUFELDER, 2001).

Agindo de forma oposta ao eixo RANK-RANK-L, a osteoprotegerina (OPG) (LACEY et al., 1998), inibe a reabsorção óssea, prevenindo a ligação entre RANKRANKL (GRAVES; COCHRAN, 2003). Não apenas os osteoblastos, mas também outras células residentes, incluindo fibroblastos do ligamento periodontal, fibroblastos gengivais e células $T$ ativadas participam da regulação de RANKL e OPG no tecido periodontal, diretamente pela produção de moléculas (tais como metaloproteinases - MMPs) ou indiretamente, através da produção de mediadores inflamatórios (GARLET et al., 2006).

\subsection{Alterações patológicas dos tecidos periodontais}

A destruição crônica do aparato de ligação periodontal devido a uma intensa resposta inflamatória a bactérias leva a um quadro clínico conhecido como doença periodontal (DP) (NAPIMOGA et al., 2009). O processo tem início com a resposta inflamatória restrita aos tecidos de proteção, conhecida como gengivite. A gengivite pode ou não evoluir para uma periodontite, dependendo de diversos fatores, tais como microbiota, e suscetibilidade do hospedeiro (DELIMA et al., 2002). Gengivite e periodontite são doenças infecciosas que afetam uma grande porcentagem da população mesmo em indivíduos jovens. A American Dental Association reporta que $48 \%$ dos adultos entre 35-44 anos apresenta inflamação na gengiva (gengivite), e $22 \%$ periodontite destrutiva (American Dental Association - Fact sheet - FY2003). Estima-se que atinja cerca de $50 \%$ dos americanos com mais de 55 anos (ALBANDAR, 2002). A do tipo severa pode resultar em dor e desconforto ocasionais, 
dificuldade de mastigação e eventuais perdas dentárias (PIHLSTROM; MICHALOWICZ; JOHNSON, 2005).

A superfície oral possui uma microflora substancial que vive em simbiose com um hospedeiro saudável. Sua microflora contém centenas de espécies de bactérias aeróbicas e anaeróbicas. Estes organismos proliferam nas superfícies dentárias como colônias interdependentes e complexas em biofilmes e ficam aderidas e densamente comprimidas contra a superfície dental em camadas mais profundas. A maturação da placa a ponto de ser relacionada à doença periodontal é associada a um aumento de bactérias gram-negativas e anaeróbicas. As bactérias mais comumente encontradas subgengivalmente em pacientes com periodontite são Porphiromonas gingivalis, Tannerella forsithensis, a espiroqueta Treponema denticola e Aggregatibacter actinomicetemcomitans (A.A.) (MANDELL; SOCRANSKY, 1981). Infecção dos tecidos periodontais com esses e outros organismos é acompanhada de liberação de proteases bacterianas como colagenases, fibrinolisinas, além de endotoxinas (SOCRANSKY; HAFFAJEE, 1994). Uma importante endotoxina é o lipopolissacarídeo (LPS), altamente antigênico e capaz de induzir a liberação de mediadores inflamatórios e citocinas tais como

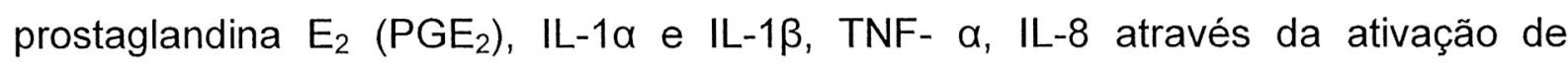
diversas linhagens celulares do hospedeiro mediada por CD14 (ligado à membrana ou solúvel no plasma) e receptores do tipo Toll (PALSSON-MCDERMOTT; O'NEILL, 2004; TATAKIS; KUMAR, 2005). Outro fator de extrema importância para a progressão da doença periodontal é o estresse oxidativo, um desequilibrio entre a produção de espécies reativas derivadas do oxigênio e os mecanismos antioxidantes inerentes ao hospedeiro (AKALIN et al., 2007; CHAPPLE; MATTHEWS, 2005). O NO é um radical livre, produzido pelas isoenzimas óxido nítrico sintases (NOS) através da conversão da L-arginina em L-citrulina (KNOWLES; MONCADA, 1994). Este radical livre parece ser de extrema importância na patogênese da periodontite, já que animais com periodontite tratados com um inibidor não seletivo de NOS (L-NAME) apresentam redução da perda óssea secundária à doença (HERRERA et al., 2010).

O processo de destruição do tecido periodontal é considerado resultado de repetidos picos de atividade seguidos de períodos de subseqüente quietude (SOCRANSKY; HAFFAJEE, 1984), cuja duração varia entre pacientes. 
Apesar de bactérias serem essenciais para a periodontite se desenvolver, o seu desenvolvimento ocorre em diversos graus em indivíduos diferentes, sugerindo uma etiologia multifatorial. Porém, todas as formas de periodontite parecem ter uma série de eventos em comum levando ao declínio tecidual e perda de aderência dentária. O epitélio juncional, devido à sua estrutura e função únicas provê uma eficiente barreira contra os patógenos periodontais e seus produtos. Porém, patógenos periodontais, em particular a Porphiromonas gingivalis, através da produção de cisteíno-proteinases que agem em moléculas de adesão e àderinas (BOSSHARDT; LANG, 2005), podem perturbar sua integridade permitindo o acúmulo de bactérias e seus antígenos na região subgengival. A resposta inflamatória que se segue leva à degradação do tecido conjuntivo subjacente, primeiramente ao redor de vasos sanguíneos e então atingindo regiões adjacentes, resultando na desintegração estrutural e funcional da gengiva. Uma das primeiras modificações na periodontite é a migração do epitélio juncional ao longo da superfície radicular e seu alongamento, resultando na formação de um epitélio juncional longo e uma bolsa gengival. Essa alteração estrutural é acompanhada por um número de alterações funcionais. A direção da migração de neutrófilos e do fluxo de exsudato crevicular através do epitélio modifica-se drasticamente já que a superfície livre do epitélio desloca-se para a superfície radicular. Além disso, a superfície livre aumenta em tamanho e dessa forma é mais exposta à placa bacteriana. O epitélio juncional precisa de um ambiente de tecido conjuntivo para se estabelecer, assim, o epitélio migra em direção ao tecido conjuntivo sadio até que este sinalize ao epitélio para cessar seu movimento em direção apical e aderir à superfície dentária (PIHLSTROM et al., 2005).

\subsection{Modelos animais de periodontite}

Apesar de haver limitações em modelos animais, eles costumam ser superiores a modelos in vitro ou estudos clínicos para responder sobre o mecanismo das doenças e são importante ligação entre hipóteses e pacientes humanos.

Estudos em animais deveriam ser avaliados em termos de sua capacidade de testar hipóteses específicas ao invés de serem fiéis a todos os aspectos de início e progressão da DP. 
Modelos animais são necessários para provar relações de causa e efeito e para testar o potencial de novas terapias. Na doença periodontal, estudos humanos são limitados pela dificuldade em estabelecer diversos fatores relacionados com o colapso periodontal.

O periodonto é uma junção de tecidos complexos que é cronicamente exposta a grande quantidade de bactérias (PASTER et al., 2006; PIHLSTROM; MICHALOWICZ; JOHNSON, 2005). Há diversas incertezas sobre quais modelos são apropriados para cada tipo de questão relativa à doença periodontal.

\subsubsection{Modelo calvário}

Foi desenvolvido para estudar o efeito de citocinas na osteoclastogênese (BOYCE et al., 1989). Foi adaptado para estudar o efeito de bactérias na reabsorção óssea (ZUBERY et al., 1998) ou interações entre hospedeiro e bactérias no tecido conjuntivo in vivo (GRAVES et al., 2001; LEONE et al., 2006). Nesse modelo, um estímulo é injetado diretamente no tecido ao redor do osso do calvário em pequeno volume. Eventos clássicos de inflamação ocorrem, tais como a rápida expressão de citocinas pró-inflamatórias e recrutamento de polimorfonucleares dentro de 24 horas (GRAVES et al., 2005). Reabsorção óssea é induzida dentro de 3 a 5 dias dependendo do tamanho do estímulo. A neoformação óssea pode ser examinada após 8-12 dias seguidos ao estímulo. Esse modelo é útil para verificar fases específicas da periodontite como reparação e invasão.

\subsubsection{Modelo da ligadura em ratos}

A colocação de ligaduras ao redor do dente para iniciar a perda tecidual periodontal vem sendo usada em diversos tipos de animais. A ligadura causa um maior acúmulo de placa e ulceração do epitélio sulcular, facilitando a invasão do tecido conjuntivo. Foi utilizado inicialmente em primatas, mas devido ao menor custo, maior facilidade de manipulação e semelhanças biológicas, o modelo em ratos passou a ser bem aceito (ROVIN; COSTICH; GORDON, 1966). No rato, perda de aderência e perda óssea ocorre em um período de sete dias (BEZERRA et al., 2000; BEZERRA et al., 2002; LOHINAI et al., 1998; NOWOTNY; SANAVI, 1983). Como em humanos, a perda de osso alveolar é dependente de bactérias. Em ratos 
gnobióticos, a colocação da ligadura não induz significante inflamação ou perda óssea periodontal (ROVIN; COSTICH; GORDON, 1966). Tratamento com clorexidina reduz a reabsorção óssea e antibióticos reduzem a perda de aderência e perda óssea, sugerindo o papel de bactérias no início da destruição nesse modelo (KENWORTHY; BAVEREL 1981; WEINER; DEMARCO; BISSADA, 1979,). Corroborando com esses resultados, a adição de outras bactérias gram-negativas aumenta a osteoclastogênese e a reabsorção óssea (SAMEJIMA; EBISU; OKADA, 1990). Também, assim como em humanos, a fase destrutivà da periodontite é associada a uma resposta do hospedeiro como mostrado pela formação de um infiltrado inflamatório antes da reabsorção óssea (GYÖRFI et al., 1994). Quando a resposta do hospedeiro é diminuída pela indução de tolerância a endotoxina, a perda óssea diminui (SAMEJIMA; EBISU; OKADA, 1990). O papel funcional da resposta inflamatória é também demonstrada pela diminuição da destruição periodontal em ratos tratados com inibidores de prostaglandinas. A indometacina reduz a inflamação gengival, formação de osteoclastos e perda óssea nesse modelo (BEZERRA et al., 2000), bem como a doxaciclina, que inibe atividade de metaloproteinases de matriz (BEZERRA et al., 2002). Ao contrário, a aplicação de IL-1 ou TNF- $\alpha$ aumenta a perda óssea causada pela ligadura (GASPERSIC et al., 2003; KOIDE et al., 1995). Uma vantagem deste modelo é a disponibilidade de modelos com doenças sistêmicas, como a diabetes, possibilitando o estudo da interação da periodontite com outras doenças.

\subsection{A relação da periodontite com outras doenças}

No final da década de 70 , galinhas livres de germes mediante infecção experimental com um com uma cepa de herpes vírus aviário apresentaram doença arterial semelhante à aterosclerose humana (MINICK et al., 1979). Este achado iniciou o paradigma "infecção sistêmica - doença cardíaca". No fim dos anos 90 , esta teoria foi expandida incluindo-se a resposta hiper-inflamatória na patogênese da doença cardiovascular.

Neste processo, infecções são capazes de causar dano indireto através da liberação de mediadores inflamatórios e causar diferentes reações relacionadas ao hospedeiro tais como respostas auto-imunes e diferentes respostas autoimunes. Assim, a proteina C-reativa (CRP) emergiu como uma anunciadora de doença 
cardiovascular futura (RIDKER et al., 1998). O paradigma de que infecção e inflamação podem apresentar um importante papel em uma variedade de doenças até então acreditado ser causado por outros mecanismos patogênicos, agora atraiu atenção para o possível papel de infecções dentárias na patogênese de doenças crônicas sistêmicas.

Nos últimos 10 anos, diversos estudos epidemiológicos verificaram a associação entre infecção oral e doença sistêmica (para revisão vide RENVERT, 2003). Esses estudos mostram que infecções orais, periodontite especificamente, podem contribuir para o risco e quadro clínico de diferentes condições sistêmicas (mortalidade, osteoporose, diabetes mellitus, infecções pulmonárias, nascimentos de baixo peso pré-termo, doenças cardiovasculares). Em experimentos animais, Streptococcus sanguis, um microorganismo oral, induz agregação plaquetária, um importante processo trombótico na formação de placa arterial (HERZBERG et al., 1992). Doenças periodontais destrutivas, que envolvem bactérias Gram-negativas, predizem doença cardíaca coronariana (BECK et al., 1996). Tanto a doença cardíaca coronariana e a doença periodontal apresentam etiologia multifatorial.

A teoria da infecção focal, promulgada entre os séculos $X I X$ e $X X$, estabelecia que os focos de sepse eram responsáveis pelo início e progressão de doenças inflamatórias como artrite, úlcera péptica e apendicite (SCANNAPIECO; PAPANDONATOS; DUNFORD, 1998). Progressos recentes na classificação e identificação de microorganismos orais, e a descoberta de que alguns microorganismos encontram-se normalmente na cavidade bucal, abriu novos caminhos para a percepção de sua importância. Tornou-se mais claro que a cavidade bucal pode agir como o sítio de origem para a disseminação de organismos patogênicos para sítios distantes, especialmente em hospedeiros imunocomprometidos.

Há fortes indicações de que o epitélio ulcerado e inflamado decorrente da periodontite constitui uma fácil porta de entrada para microorganismos. Bacteremias devem ocorrer diversas vezes ao dia. Além disso, endotoxina bacteriana (LPS) e todos os tipos de antígenos bacterianos podem ser disseminados através do corpo originando-se da lesão periodontal. Ainda, deve-se esperar que os mediadores imunes pró-inflamatórios produzidos localmente como IL-1, IL-6, TNF-a,e PGE 2 , sejam liberados na circulação sanguínea e subsequentemente possam exercer 
efeitos em órgãos periféricos. O hospedeiro responde a essas agressões de forma similar a outras infecções ou processos inflamatórios (LOOS, 2005). Tanto P. gingivalis quanto $A$. actinomycetemcomitans, e $T$. denticola são capazes de invasão tecidual (SOCRANSKY; HAFFAJEE, 2002). Os dentes são a única superfície do corpo que não sofre descamação e o número de bactérias pode chegar a mais de $10^{11}$ microorganismos por miligrama de placa dental.

Relatos recentes mostram que uma das vias da influência da periodontite em sítios extremos é o aumento de componentes pró-oxidativos, tais como metabólitos reativos de oxigênio (ROS), bem como a diminuição do potencial anti-oxidante biológico do plasma (D'AIUTO et al., 2010). Dados de nosso laboratório mostram que em órgãos periféricos como coração a periodontite induz alterações no conteúdo de resíduos protéicos de 3-nitrotirosina (HERRERA et al., 2010), um marcador indireto da produção de óxido nítrico formado pela reação entre o óxido nítrico e outro radical livre derivado do oxigênio, o ânion superóxido gerando peroxinitrito, o qual pode reagir com resíduos aromáticos de aminoácidos, dando origem à sua nitração (KAUR; HALLIWELL, 1994). Assim, pode-se propor um novo papel para o óxido nítrico, mediando os efeitos sistêmicos da periodontite.

\subsection{Alterações vasculares mediadas pela periodontite}

Junto com o sistema parassimpático, o sistema nervoso simpático constitui o sistema nervoso autônomo (GUYTON, 2000). Neurônios aferentes do SNS são múltiplos (como quimioreceptores, baroreceptores, receptores viscerais), e o cérebro é o centro coordenador (núcleo cerúleo, medula oblongata). Outros núcleos simpáticos estão localizados no cérebro médio e no hipotálamo posterior. O SNS consiste de dois neurônios conectados, os quais fazem sinapse na cadeia simpática. De quatro níveis (cervical, torácico, lombar, pélvico), o segundo neurônio deixa a cadeia simpática para os órgãos efetores.

Os principais transmissores do SNS são epinefrina, norepinefrina e dopamina. A maior parte da epinefrina é produzida por células cromafins da medula adrenal, armazenada em vesículas e secretada na corrente sanguínea por exocitose (DÜNSER; HASIBEDER, 2009). $80 \%$ da produção de hormônio realizada pela adrenal é epinefrina, enquanto a norepinefrina corresponde aos outros $20 \%$. A 
principal fonte de norepinefrina extra-adrenal são os neurônios simpáticos pósganglionares. Após sua secreção na fenda sináptica, a norepinefrina é retomada por terminações nervosas, degradada pela catecol-O-metiltransferase ou difundida ao espaço extra-sináptico ou corrente sanguínea. As catecolaminas presentes na circulação são degradas mais lentamente, por vias não-enzimáticas (recaptação extraneural nos pulmões, rins, intestinos, e recaptação neural em terminações nervosas simpáticas pós-sinápticas) e enzimáticas (monoamina-oxidase em terminações nervosas simpáticas)

Os receptores adrenérgicos são divididos em $\alpha\left(\alpha_{1}\right.$ e $\left.\alpha_{2}\right)$ e $\beta\left(\beta_{1}, \beta_{2}\right.$ e $\left.\beta_{3}\right)$. Três subtipos de receptores $\alpha_{1}$ foram descritos (A, B, D) (DOCHERTY, 2010). Todos os receptores adrenérgicos são acoplados à proteína $\mathrm{G}$ estimulatórias ou inibitórias. A estimulação de receptores a ativam a cascata da fosfolipase, enquanto que a estimulação de receptores $\beta$ são acoplados à via da adenililciclase, que regula a aminofosfatase cíclica (AMPc) intracelular. Os receptores $\alpha_{1}$ estão presentes no músculo liso vascular, e sua ativação causa vasoconstrição. Ao ser ativados por seu ligante, uma proteína heterodimérica $G$, chamada $G_{q}$, ativa a fosfolipase $C$, que cliva o fosfatidilinositol 4,5-bifosfato $\left(\mathrm{PIP}_{2}\right)$ a inositol trifosfato $\left(\mathrm{IP}_{3}\right)$ e diacilglicerol (DAG). $\mathrm{O} \mathrm{IP}_{3}$ interagem com os canais de cálcio do retículo sarcoplasmático, liberando o cálcio que estava retido para o citoplasma.

O relaxamento mediado pela acetilcolina é dependente do endotélio. Este mediador colinérgico age sobre o seu receptor em células endoteliais, $M_{3}$, o que provoca um aumento na concentração de cálcio intracelular, formando um complexo de cálcio-calmodulina, a ativação de eNOS, conduzindo à produção de NO pela conversão de L-arginina a L-citrulina. O NO formado irá difundir para dentro da célula muscular e ativar a enzima guanilato ciclase que converte GTP para cGMP causando o relaxamento muscular.

Sabe-se que a superprodução de óxido nítrico estimulada por mediadores pró-inflamatórios durante a sepse ou resposta inflamatória sistêmica induz uma redução quantitativa e qualitativa de receptores adrenérgicos (BUCHER et al., 2003).

Em tecidos não inflamados, as células endoteliais vasculares são responsáveis pela manutenção do fluxo sanguíneo através de mecanismos que inibem a coagulação intravascular, regulam o fluxo de sangue, controlam a permeabilidade vascular, inibem a ativação de leucócitos circulantes e a adesão endotelial (POBER; SESSA, 2007). Além disso, células endoteliais inibem a adesão 
e agregação plaquetária através da liberação de óxido nítrico (NO). O NO é produzido por um grupo de isoenzimas coletivamente denominados NO sintases (NOS). As NOS existem como três isoformas distintas, a saber NOS endotelial (eNOS), NOS neuronal (nNOS) e a NOS induzivel (iNOS). Tanto eNOS quanto nNOS são isoformas constitutivas e produzem pequenas quantidades de NO durante um curto período de tempo. Em contraste iNOS é uma isoforma induzível, expressa em resposta a estímulos pró-inflamatórios (endotoxina de bactérias Gramnegativas, isoladamente ou em conjunto com certas citocinas) e produz uma grande quantidade de NO durante longos períodos de tempo, e assim em maiores quantidades. NO produzido em alta concentração local pode atuar como uma molécula citotóxica agindo contra fungos, bactérias, protozoários organismos assim como células tumorais (MONCADA, 1992).

A COX-1 e COX-2 são enzimas ligadas a proteínas de membrana que residem, após a síntese e transporte, principalmente no retículo endoplasmático. $\mathrm{O}$ primeiro passo na formação de prostaglandinas é a liberação de ácido araquidônico a partir de fosfolípides ligados a membrana, geralmente por ação da fosfolipase $A_{2}$. As isoformas de COX então produzem duas prostaglandinas precursoras prostaglandina $\mathrm{G} 2\left(\mathrm{PGG}_{2}\right)$ que então é convertida a prostglandina $\mathrm{H}_{2}\left(\mathrm{PGH}_{2}\right)$ através de processos enzimáticos idênticos. Após estas etapas, $\mathrm{PGH}_{2}$ pode ser metabolizada por vias diferentes em uma gama de produtos com potentes efeitos biológicos (WARNER; MITCHELL, 2004). Prostanóides (prostaglandinas, tromboxanos e prostaciclina) são a principal classe de eicosanóides vasoativos. Existe evidência considerável de que a prostaciclina $\left(\mathrm{PGI}_{2}\right)$, juntamente com NO (ambos de origem endotelial), tenha um papel importante na regulação do tônus vascular e pressão arterial, fazendo com que os efeitos vasodilatadores diretamente ou por modulação das ações de outros mediadores vasoativos tais como angiotensina II, catecolaminas, arginina-vasopressina e endotelina (KATUSIC; SHEPHERD, 1991). Em contraste, o tromboxano $A_{2}$ (TXA $)$, prostanóide vasoconstritor é produzido principalmente por plaquetas, e em quantidades muito menores por alguns vasos sistêmicos (SMITH et al., 1986). Acredita-se que o equilíbrio entre a produção de $\mathrm{TXA}_{2}$ em plaquetas por COX-1 e prostaciclina $\left(\mathrm{PGI}_{2}\right)$ produzida por COX-2 é também importante para a manutenção do tônus vascular.

O fluxo sanguíneo é regulado por um balanço de sinais que aumentam ou diminuem o tônus das camadas adjacentes de células musculares lisas (BUSSE; 
FLEMING, 2004). A produção de NO basal contribui para a quiescência endotelial por expressão do gene da inibição de mediadores pró-inflamatórios (DECATERINA et al., 1995). A falha em qualquer um destes mecanismos é conhecido como disfunção endotelial.

Recentemente, estudos demonstraram que pacientes com periodontite apresentam uma deficiência da vasodilatação dependente de endotélio. (AMAR et al., 2003; HIGASHI et al., 2009). Também foi mostrado que mediante terapia periodontal apropriada houve restabelecimento da função vasomotora dos pacientes, sem qualquer alteração da função muscular lisa dos vasos. Uma possível teoria é que a inflamação crônica causada pela periodontite esteja envolvida com a disfunção endotelial através de uma diminuição da produção, biodisponibilidade e/ou efeitos celulares do NO (HIGASHI et al., 2009).

Entretanto, não há na literatura relatos que correlacionem alterações vasculares com periodontite em modelos animais, a partir dos quais possam ser estudados em profundidade os mecanismos envolvidos.

O tratamento com L-NAME ou Etoricoxib ter um efeito positivo sobre a perda óssea causada por periodontite. O objetivo deste estudo foi investigar a relação entre a periodontite e da reatividade vascular, e sugerir um novo mecanismo pelo qual a periodontite exerceria seu efeito sobre o aparelho cardiovascular. Também foi investigada a participação de COX-1, COX-2, eNOS e iNOS, enzimas que comprovadamente têm um papel-chave no curso da periodontite. 


\section{OBJETIVOS}

Tendo em vista a potencial importância dos efeitos da doença periodontal em órgãos à distância, em especial sobre o aparelho cardiovascular, o presente trabalho teve como objetivos avaliar a influência da periodontite induzida por ligadura em ratos sobre a pressão arterial e a reatividade vascular in vitro. 


\section{MATERIAL E MÉTODOS}

\subsection{Animais}

Ratos Wistar machos (180-200 g) foram divididos em grupos de cinco animais por gaiola. Eles receberam água e ração ad libitum e foram mantidos sob ciclo claro/escuro de doze horas em ambiente com temperatura controlada ( $23 \pm 2$ ${ }^{\circ} \mathrm{C}$ ). Todos os experimentos foram aprovados pelo Comitê de Ética no uso de animais do ICB/USP.

Todos os experimentos foram realizados após anestesia dos animais pela administração intraperitoneal (i.p.) de uma mistura de quetamina $\left(80 \mathrm{mg} \mathrm{kg}^{-1}\right) \mathrm{e}$ xilazina $\left(20 \mathrm{mg} \mathrm{kg}^{-1}\right)$.

\subsection{Indução de periodontite}

Após anestesia, fio de sutura de algodão foi passado em torno da cervical dos primeiros molares inferiores direitos dos animais. $\mathrm{O}$ fio foi atado pela face vestibular do dente, passou de forma subgengival para o lado lingual e supragengival para o lado vestibular. No grupo de animais controle, o fio de sutura foi retirado imediatamente após o procedimento.

\subsection{Tratamento dos animais}

Para avaliar a participação da $\mathrm{PGI}_{2}$ no protocolo, realizou-se tratamento com inibidor específico de COX-2, Etoricoxib. De forma a avaliar a participação do NO, utilizou-se um inibidor não seletivo de NOS, L-nitro arginina metil-éster (L-NAME). Os animais foram divididos em 3 grupos - Etoricoxib (Eto $-10 \mathrm{mg} / \mathrm{kg} / \mathrm{dia}$, administrado por via oral empregando agulha para gavagem), L-NAME (LN aproximadamente $45-60 \mathrm{mg} / \mathrm{kg} / \mathrm{dia}$ administrados pela água de beber, na concentração de $200 \mathrm{mg} / \mathrm{L}$ ). $O$ tratamento dos animais teve início 3 dias antes da indução da doença periodontal e foi mantido até a morte dos animais, 7 dias após a indução de periodontite. 
A suspensão de Etoricoxib foi preparada sempre no mesmo dia de sua administração, (pela manhã), a partir de comprimidos de Arcoxia (MSD - Etoricoxib $90 \mathrm{mg}$ ), os quais foram pesados, macerados com gral e pistilo de cerâmica e suspensos em carboximetilcelulose (CMC) 0,5\% para uma concentração final de 10 $\mathrm{mg} / \mathrm{mL}$.

A solução de $200 \mathrm{mg} / \mathrm{L}$ de L-NAME (Sigma-Aldrich) em água potável filtrada (administrada aos animais do grupo LN) também foi prearada diariamente e colocada nos bebedouros dos animais.

\subsection{Mensuração da pressão sanguínea sistólica (PA)}

Um dia antes do início dos tratamentos e seis dias após o procedimento de colocação da ligadura, a pressão sanguínea sistólica foi determinada em ratos conscientes pelo método indireto de pletismógrafo de manguito de cauda. Ratos foram pré-aquecidos a $40{ }^{\circ} \mathrm{C}$ por $5 \mathrm{~min}$ prévios às medidas de $\mathrm{PA}$, e então 3 medidas consecutivas da pressão sanguínea foram realizadas.

\subsection{Tratamento in vitro}

Quinze minutos antes do início dos experimentos de reatividade vascular as seguintes drogas, separadamente, foram aplicadas diretamente na cuba. $O$ inibidor inespecífico de NOS, L-NAME (concentração final de $100 \mu \mathrm{M}$ ), o inibidor específico de iNOS, 1400W (concentração final de $1 \mu \mathrm{M}$ ), o inibidor de COX-1 e COX-2, indometacina (concentração final de $10 \mu \mathrm{M}$ ), o inibidor de COX-1, SC560 (concentração final de 9 nM), o inibidor de COX-2, NS398 (concentração final de 1 $\mu \mathrm{M})$. Após o tempo de incubação foram realizados os experimentos de reatividade vascular através de curvas concentração-resposta à norepinefrina e acetilcolina.

\subsection{Preparação de anéis de aorta isolados}

Após o sacrifício dos animais, a aorta torácica foi retirada e o tecido gorduroso ao seu redor foi removido mantendo o tecido constantemente em uma solução de 
Krebs contendo (em mM): $\mathrm{NaCl}, 130 ; \mathrm{NaHCO}_{3}, 14.9 ; \mathrm{KCl}, 4.7 ; \mathrm{KH}_{2} \mathrm{PO}_{4}, 1.18$; $\mathrm{MgSO}_{4} \cdot 7 \mathrm{H}_{2} \mathrm{O} 1.18 ; \mathrm{CaCl}_{2} \cdot 2 \mathrm{H}_{2} \mathrm{O}, 1.56$, EDTA, 0.026, glicose 5.5.

Segmentos de aorta torácica (4 $\mathrm{mm}$ de comprimento) foram cuidadosamente cortados e montados como preparações de anéis em câmaras padrão de órgãos para registro de tensão isométrica através do sistema PowerLab 8/SP para aquisição de dados (ADInstruments Pty Ltd., Castle Hill, Australia). Os tecidos foram mantidos na solução de Krebs, continuamente borbulhados com $95 \%$ de $\mathrm{O}_{2}$ e $5 \%$ de $\mathrm{CO}_{2}$ e mantidos a $37^{\circ} \mathrm{C}$, sob uma tensão de repouso $(1,5 \mathrm{~g}$, ajustada durante 60 minutos antes da adição dos agentes farmacológicos vasoativos). Após esse período, a integridade dos vasos foi verificada pela adição de cloreto de potássio $(\mathrm{KCl}-84 \mathrm{mM})$, durante 15 minutos. Os vasos foram lavados com solução de Krebs (4 vezes durante $15 \mathrm{~min}$ cada uma), a tensão foi novamente ajustada para $1,5 \mathrm{~g}$ e então iniciou-se a aplicação de norepinefrina (NE). Concentrações crescentes de norepinefrina foram aplicadas de forma cumulativa (compreendidas entre $10^{-10} \mathrm{M}$ e $3^{*} 10^{-5} \mathrm{M}$ ) e mantidas por 3 minutos até o registro do valor de tensão.

Para a análise de relaxamento dependente de endotélio, os anéis de aorta foram pré-contraídos com $10^{-4} \mathrm{M}$ de $\mathrm{NE}$, e então realizou-se a adição de concentrações cumulativas de acetilcolina ( $\mathrm{ACh}, 10^{-10} \mathrm{M}$ até $10^{-4} \mathrm{M}$ ).

\subsection{Análise de expressão gênica pela reação em cadeia da polimerase em tempo real (RT-PCR)}

As aortas foram congeladas em gelo seco e mantidas a $-80{ }^{\circ} \mathrm{C}$ previamente à extração de RNA. O RNA total foi extraído utilizando-se o reagente TRIZOL (GIBCOBRL, USA) e seguindo as instruções do fabricante. O cDNA foi sintetizado a partir de $10 \mu \mathrm{g}$ do RNA total, usando Superscript II (Life Technologies, GIBCO-BRL, Gaithersburg, MD, USA) e armazenado $a-20{ }^{\circ} \mathrm{C}$ até sua utilização. RT-PCR foi realizado utilizando-se Sybr Green para quantificar a expressão de cada isoforma de COX, bem como as isoformas endotelial e induzível da NOS. A normalização foi realizada utilizando como controle interno a expressão gênica da hipoxantinaguanina fosforibosiltransferase (HPRT). Todos os primers apresentaram eficiência $>90 \%$ conforme o requerido para a quantificação através do algoritmo $2^{-\triangle \Delta C t}$. As sequências específicas dos primers utilizados encontram-se no quadro abaixo: 
Quadro 1 - Sequências específicas dos primers utilizados nos experimentos de PCR em tempo real

\begin{tabular}{|l|l|l|}
\hline Gene & Sequência “forward" $\left(\mathbf{5}^{\prime} \mathbf{- 3} \mathbf{\prime}\right)$ & Sequência “reversa" $\left(\mathbf{5}^{\prime} \mathbf{- 3}\right.$ ') \\
\hline COX-1 & CGTGTGTGTGACTTGCTGAA & GGTTGCGATACTGGAACTGG \\
\hline COX-2 & ACATTCCCTTCCTTCGGAAT & AAGGGCCCTGGTGTAGTAGG \\
\hline eNOS & AGCATGAGGCCTTGGTATTG & CCCGACATTTCCATCAGC \\
\hline iNOS & AAAATGGTTTCCCCCAGTTC & GTGGATGGAGTCACATGCAG \\
\hline HPRT & TATGCCGAGGATTTGGAAAA & ACAGAGGGCCACAATGTGAT \\
\hline
\end{tabular}

Fonte: Muscará, 2011.

\subsection{Análise da expressão de resíduos protéicos de COX-2 e NOS endotelial (eNOS) por Western blot}

\subsubsection{Preparação das amostras}

As amostras de tecidos foram pesadas e homogeneizadas em tampão TRIS$\mathrm{HCl} 50 \mathrm{mM}, \mathrm{pH}$ 7,4, contendo $1 \mathrm{mM}$ de PMSF numa proporção de cinco volumes de tampão por grama de tecido. Em seguida, as amostras foram centrifugadas a 10.000 $g$ por 2 min e os sobrenadantes foram submetidos às análises de NT e iNOS por Western blot. A concentração de proteínas totais nos homogenatos de tecidos foi determinada através do método de Braford (1976).

\subsubsection{Eletroforese}

As amostras foram diluídas em tampão TRIS-HCl $50 \mathrm{mM}, \mathrm{pH} 7,4$ contendo mercaptoetanol e azul de bromofenol na concentração final de $50 \mu \mathrm{g}$ de proteína para cada $20 \mu \mathrm{L}$ de amostra. As amostras foram centrifugadas por $15 \mathrm{~s}$ a $10,000 \mathrm{ge}$ aplicadas no gel de SDS-PAGE a 10\% (para nitrotirosina) e 15\% (para iNOS). Para ambas as corridas eletroforéticas, foram aplicadas $5 \mu \mathrm{L}$ da solução de marcadores de peso molecular, $20 \mu \mathrm{L}$ de cada amostra (concentração final: $2,5 \mu \mathrm{g} / \mu \mathrm{L}$ ) e $6 \mu \mathrm{L}$ do controle positivo (albumina nitrada para 3-NT e homogenato de pulmão proveniente de ratos com sepse para iNOS) na concentração de $0.38 \mu \mathrm{g} / \mu \mathrm{L}$. As proteinas foram 
separadas por eletroforese aplicando uma corrente constante de $35 \mathrm{~mA}$ durante aproximadamente duas horas.

\subsubsection{Transferência}

A transferência das proteínas do gel foi feita eletroforeticamente para uma membrana de nitrocelulose.. Esse sistema também foi ligado à fonte, fixando-se o valor da corrente em $150 \mathrm{~mA}$, durante duas horas. Após este período, as membranas foram coradas com solução de vermelho de Ponceau a fim de verificar a eficiência da transferência. Posteriormente, as membranas foram lavadas com solução de tampão Tris-salina adicionado de 0,5\% de Tween 20 (TBS-t).

\subsubsection{Bloqueio de sítios inespecíficos e incubação com os anticorpos}

O bloqueio de sítios inespecíficos presentes nas membranas de nitrocelulose foi realizado através da incubação das membranas com uma solução de caseína (0,2\% em TBS-t) por uma hora, sob agitação contínua.

Após este periodo, as membranas foram incubadas com o anticorpo primário anti nitro-tirosina (camundongo), ou com o anticorpo primário anti-iNOS na mesma diluição (500 ng/mL em TBS-t), durante 16 hs sob agitação contínua a $18^{\circ} \mathrm{C}$.

A seguir, as membranas foram lavadas com TBS-t (6 vezes durante $10 \mathrm{~min}$ ), sob agitação a temperatura ambiente. Após as lavagens, as membranas foram incubadas com o anticorpo secundário de coelho anti-camundongo conjugado com fosfatase alcalina na diluição de 1:3000 em TBS-t por duas horas. As membranas foram posteriormente lavadas com TBS-t (6 vezes durante 10min) e finalmente submetidas à revelação das bandas imunorreativas.

\subsubsection{Revelação}

Partes iguais de reagente de luminol e solução de peróxido foram utilizadas para incubar as membranas durante 5 minutos (kit Immobilon Western - Millipore). A captação dos sinais de quimioluminiscência foi feita num sistema Chemilmager 5500 (Alpha Innotech Corporation, CA, EUA. As intensidades das bandas foram 
quantificadas por densitometria, empregando-se o software que acompanha o sistema de aquisição de imagens.

\subsection{Análise estatistica}

A maior parte dos dados foi obtido de 2 a 3 experimentos realizados em diferentes ocasiões e os resultados expressos como média \pm SEM. A maior parte dos dados foi analisada por ANOVA de uma via seguido de teste de Bonferroni para múltiplas comparações. Os dados de RT-PCR foram analisados por teste t pareado. Valores de $\mathrm{p}$ inferiores a 0.05 foram considerados estatisticamente significantes. 


\section{RESULTADOS}

Como visto na Figura 1, as aortas de animais com periodontite têm menor contração mediada pela norepinefrina do que os animais sham $(2,16 \pm 0,13 \mathrm{~g}$ vs $2,68 \pm 0,12 \mathrm{~g}, \mathrm{p}<0,05, \mathrm{n}=8)$. Esta diferença ocorre apenas na presença do endotélio (painel A). A dilatação mediada pela acetilcolina (Figura 2), bem como ocorre na contração com norepinefrina, é também diminuída em aortas de animais com periodontite $(71,87 \pm 2,22 \%$ vs $43,53 \pm 2,65 \%, p<0.001, n=8)$.

$\mathrm{Na}$ Figura 3, vemos que o tratamento in vitro com um inibidor inespecífico da óxido nítrico sintase, L-NAME, causa aumento da contração mediada por norepinefrina em aortas de animais com periodontite $(2,90 \pm 0,25 \mathrm{~g}$ vs $2,08 \pm 0,13$ $g, p<0,05)$ e de animais sham $(3,20 \pm 0,23 g$ vs $2,63 \pm 0,06 g, p<0,05)$. A Figura 4 mostra que o tratamento in vitro com um inibidor específico de iNOS, $1400 \mathrm{~W}$ não causou efeito sobre a contração mediada por norepinefrina tanto em aortas de animais sham quanto de animais com periodontite.

O bloqueio de ambas as isoformas da COX por tratamento com indometacina in vitro causou uma diminuição na contração à norepinefrina somente em aortas de animais sham (Figura $5-2,04 \pm 0,12 \mathrm{~g}$ vs $2,63 \pm 0,06 \mathrm{~g}, \mathrm{p}<0,05$ ), enquanto que não teve efeito sobre aortas de animais com periodontite. A Figura 6 mostra que o tratamento in vitro com um inibidor de COX-1 específico, SC560 não teve efeito sobre a contração mediada por norepinefrina tanto em aortas de animais com periodontite quanto em aortas de animais sham. Na Figura 7, podemos observar que a inibição específica de COX-2 através de tratamento in vitro com NS398 causou diminuição da contração mediada por norepinefrina tanto em aortas de animais com periodontite $(1,59 \pm 0,21 \mathrm{~g}$ vs $2,08 \pm 0,12 \mathrm{~g}, \mathrm{p}<0,05)$ quanto de animais sham $(1,59$ $\pm 0,18 \mathrm{~g}$ vs $2,63 \pm 0,06 \mathrm{~g}, \mathrm{p}<0,001)$.

A Figura 8 mostra que o tratamento in vitro com L-NAME aboliu o relaxamento mediado pela acetilcolina, tanto em aortas de animais com periodontite quanto em aortas de animais sham. A Figura 9 mostra que o tratamento in vitro com $1400 \mathrm{~W}$ causou um aumento do relaxamento mediado por acetilcolina em aortas de animais com periodontite $(43,13 \pm 2,37 \%$ vs $32,63 \pm 4,76 \%, p<0,01)$ e diminuição do relaxamento mediado por acetilcolina em aortas de animais sham $(39,57 \pm 4,02 \%$ vs $56,48 \pm 2,64 \%, p<0,05)$. 
$\mathrm{Na}$ Figura 10 observa-se que o tratamento in vitro com indometacina causou um aumento no relaxamento mediado por acetilcolina somente em aortas de animais com periodontite $(51,65 \pm 2,46 \%$ vs $32,63 \pm 4,76 \%, p<0,01)$. A Figura 11 mostra que a inibição específica de COX-1 utilizando SC560 não teve qualquer efeito sobre o relaxamento mediado por acetilcolina em ambos os grupos. A inibição específica da COX-2 usando NS398 (Figura 12) teve efeito similar ao tratamento com indometacina, aumentando somente $\mathrm{o}$ relaxamento $\mathrm{em}$ aortas de animais periodontite $(45,70 \pm 0,40 \%$ vs $32,63 \pm 4,76 \%, p<0,01)$.

A Figura 13 mostra que o tratamento in vivo com L-NAME causou um aumento na contração mediada por norepinefrina em aortas de animais com periodontite tanto na presença $(3,52 \pm 0,07 \mathrm{~g}$ vs $2,16 \pm 0,13 \mathrm{~g}, \mathrm{p}<0,001)$ quanto na ausência de endotélio $(5,57 \pm 0,45 \mathrm{~g}$ vs $3,08 \pm 0,33 \mathrm{~g}, \mathrm{p}<0,001)$. O mesmo tratamento não teve efeito em aortas de animais sham.

A Figura 14 mostra que, o tratamento in vivo com um inibidor específico de COX-2, Etoricoxib causou diminuição da contração mediada pela norepinefrina em animais sham $(2,00 \pm 0,11 \mathrm{~g}$ vs $2,68 \pm 0,12 \mathrm{~g}, \mathrm{p}<0,01)$.

A Figura 15 mostra que o tratamento in vivo com L-NAME causou uma diminuição no relaxamento mediado pela acetilcolina em aortas de animais sham $(29,34 \pm 2,22 \%$ vs $56,48 \pm 2,64 \%, p<0,001)$, enquanto não teve efeito sobre aortas de animais do grupo periodontite.

A Figura 16 mostra que o tratamento in vivo Etoricoxib causou um aumento no relaxamento mediado pela acetilcolina em aortas de animais com periodontite $(41,77 \pm 2,20$ vs $32,63 \pm 4,76 \%, p<0,05)$, enquanto não teve efeito sobre aortas de animais sham.

Na Figura 17 o painel A mostra que a contração mediada por $\mathrm{KCl}$ é diminuída em aortas de animais com periodontite com endotélio $(2,71 \pm 0,14 \mathrm{~g}$ vs $3,38 \pm 0,25$ $\mathrm{g}, \mathrm{p}<0,05)$. O tratamento com Etoricoxib causou uma diminuição na contração mediada por $\mathrm{KCl}$ em aortas de animais sham com endotélio $(2,58 \pm 0,23 \mathrm{~g}$ vs $3,38 \pm$ $0,25 \mathrm{~g}, \mathrm{p}<0,05)$. O painel B mostra que, na ausência da camada endotelial, aortas de animais periodontite também apresentam contração diminuída ao $\mathrm{KCl}(2,71 \pm$ $0,19 \mathrm{~g}$ vs $3,16 \pm 0,15 \mathrm{~g}, \mathrm{p}<0,05)$. O tratamento com L-NAME $(2,72 \pm 0,11 \mathrm{~g}$ vs 3,16 $\pm 0,15 \mathrm{~g}, \mathrm{p}<0,05)$ e Etoricoxib $(2,60 \pm 0,02 \mathrm{~g}$ vs $3,16 \pm 0,15, \mathrm{p}<0,01)$ causaram uma diminuição na contração de $\mathrm{KCL}$ em aortas de animais sham. 
Na Figura 18 observa-se que a indução da periodontite não teve efeito sobre a pressão sanguínea de ratos. O tratamento com L-NAME causou um aumento da pressão arterial tanto em animais com periodontite $(154,00 \pm 1,80 \mathrm{mmHg}$ vs 122,60 $\pm 1,20 \mathrm{mmHg}, \mathrm{p}<0,001)$ quanto em animais sham $(157,68 \pm 2,08 \mathrm{mmHg}$ vs 122,02 $\pm 0,65 \mathrm{mmHg}, \mathrm{p}<0,001)$. O tratamento com Etoricoxib também causou um aumento da pressão arterial tanto no grupo periodontite $(131,40 \pm 1,40 \mathrm{mmHg}$ vs 120,40 \pm $1,00 \mathrm{mmHg}, p<0,001)$ quanto no grupo sham $(138,42 \pm 1,19 \mathrm{mmHg}$ vs $125,59 \pm$ $1,53 \mathrm{mmHg}, \mathrm{p}<0,001)$.

A Figura 19 mostra que a expressão de mRNA para COX-1 é semelhante em amostras da aorta do grupo periodontite e sham. Curiosamente, o tratamento com LNAME em animais sham resultou num aumento na expressão de mRNA para esta enzima (Painel B -5,18 $\pm 1,08 \Delta \Delta C T$ vs. 1,00 $\Delta \Delta C T, p<0,05, n=8$ ).

A Figura 20 mostra que a expressão de mRNA para COX-2 encontra-se aumentada em amostras de animais com periodontite $(3,09 \pm 0,91 \triangle \triangle \mathrm{CT}$ vs. 1,00 $\Delta \triangle \mathrm{CT}, \mathrm{p}<0,05, \mathrm{n}=8$ ), e esta expressão aumenta quando os animais são tratados com L-NAME, um fenômeno que ocorre em ambos os grupos. Também em ambos, a expressão do mRNA de COX-2 após tratamento com o seu inibidor específico, Etoricoxib encontra-se diminuída (Periodontite $-0,44 \pm 0,17 \Delta \Delta C T$ vs. $1,00 \Delta \Delta C T, p$ $<0,05, \mathrm{n}=8$ ), (Sham- $0,57 \pm 0,19$ vs. $1,00 \Delta \triangle \mathrm{CT}, \mathrm{p}<0,01, \mathrm{n}=8$ ).

A Figura 21 mostra que a indução da periodontite provoca uma diminuição da expressão do mRNA para eNOS $(0,15 \pm 0,02$ vs $1,00 \Delta \triangle \mathrm{CT} \triangle \Delta \mathrm{CT})$. O tratamento com Etoricoxib provoca uma diminuição da expressão de eNOS apenas em animais sham $(0,10 \pm 0,03 \triangle \triangle C T$ vs.1 $\triangle \triangle C T)$. O tratamento com L-NAME não teve efeito sobre a expressão de mRNA para eNOS mRNA em animais sham e em animais com periodontite.

A Figura 22 mostra que a indução de periodontite causou uma diminuição na expressão do mRNA para iNOS $(2,31 \pm 0,39 \Delta \Delta C T$ vs. $1 \Delta \Delta C T, p<0,05)$. Em aortas de animais sham, o tratamento com Etoricoxib causou uma diminuição na expressão do mRNA para iNOS $(0,20 \pm 0,06 \triangle \triangle \mathrm{CT}$ vs. $1 \triangle \triangle \mathrm{CT}, \mathrm{p}<0,05)$.

A Figura 23 mostra a expressão proteica de COX-2 nas amostras de aorta de animais sham e periodontite. Podemos ver que há aumento da expressão de COX-2 em animais com periodontite $(39,67 \pm 2,84$ A.U. vs. $15,63 \pm 0,84$ A.U., $p<0,01, n=$ 5). 
Figura 1 - Efeito da periodontite sobre a contração dos anéis de aorta de rato com (E +) ou sem (E-) endotélio em resposta à norepinefrina.
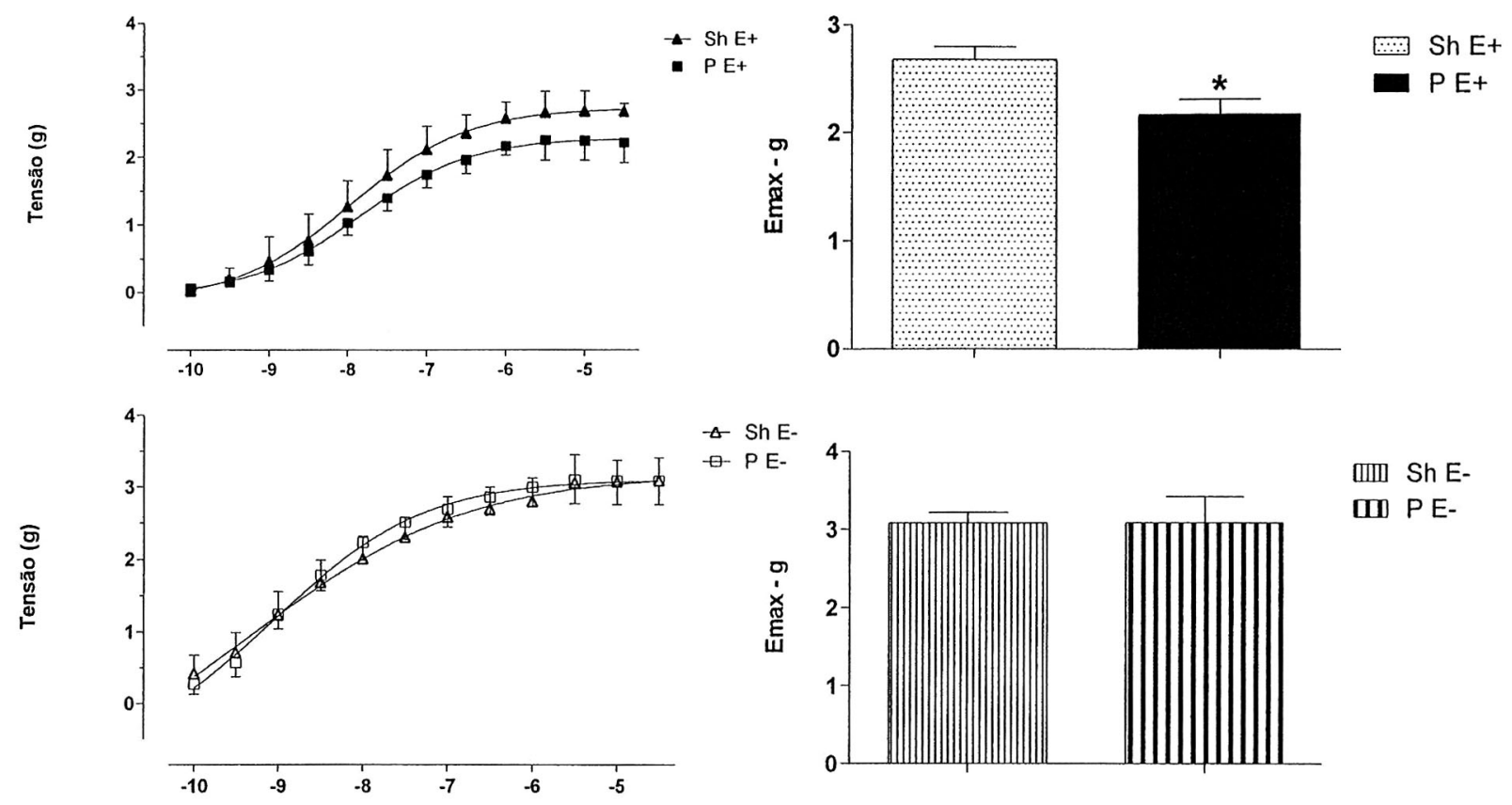

띤 Sh E-

U11 $P E$ -

Painel A - Curva concentração-resposta para a norepinefrina em anéis de aorta com endotélio em animais sham ou com periodontite. Painel B - tensão máxima (Emax) em gramas obtida por anéis de aorta com endotélio de animais sham ou com periodontite, em resposta a norepinefrina. ${ }^{*}=p<0,05$ comparado ao controle $(n=8)$. Painel C Curva concentração-resposta à norepinefrina em anéis de aorta sem endotélio de animais sham ou com periodontite. Painel $D$-tensão máxima (Emax) em gramas obtidos por anéis de aorta sem endotélio de animais sham ou com periodontite, em resposta a norepinefrina $(n=8)$.

FONTE: Muscará, 2010. Com permissão. 
Figura 2 - Efeito da periodontite sobre a dilatação de anéis de aorta de rato em resposta à acetilcolina.

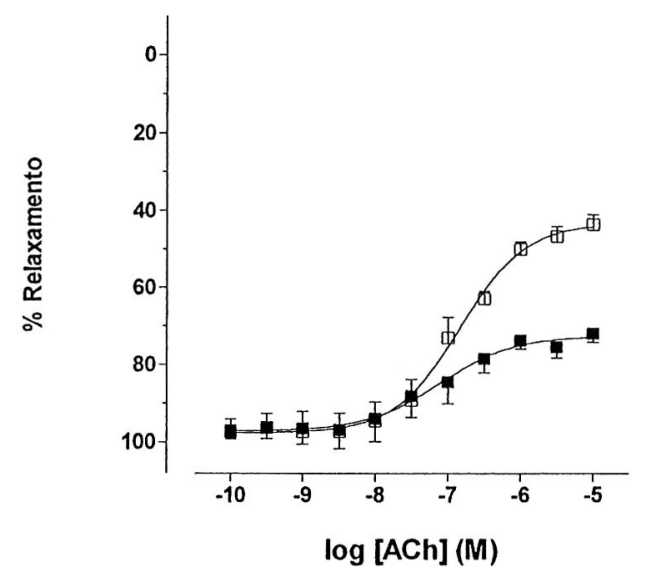

$\square \mathrm{Sh}$

- $P$

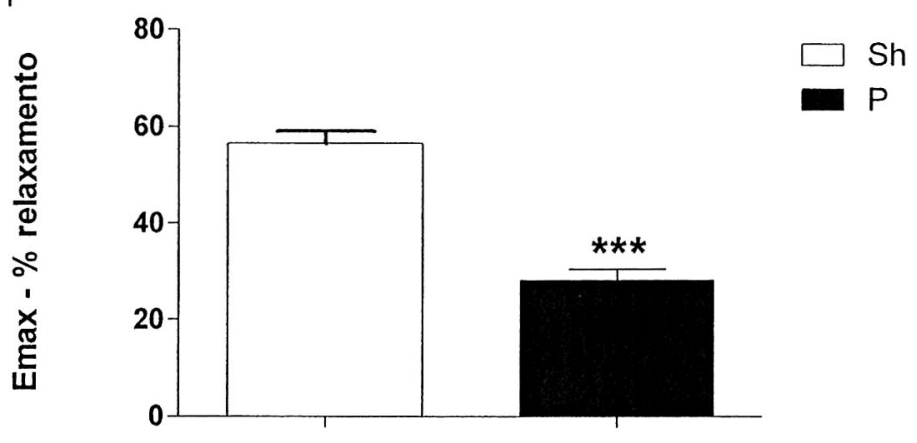

Painel A - Curva concentração-resposta para a acetilcolina em anéis de aorta de animais sham ou com periodontite. Painel B - relaxamento máximo (Emax) em percentagem obtida por anéis de aorta de animais sham ou periodontite, em resposta a acetilcolina. ${ }^{* * *}=\mathrm{P}$ $<0,001$ em comparação com o controle $(n=8)$.

FONTE: Muscará, 2010. Com permissão.

Figura 3 - Efeito do tratamento in vitro com L-NAME (LN) sobre a resposta pressora à norepinefrina em anéis de aorta de animais sham ou periodontite.
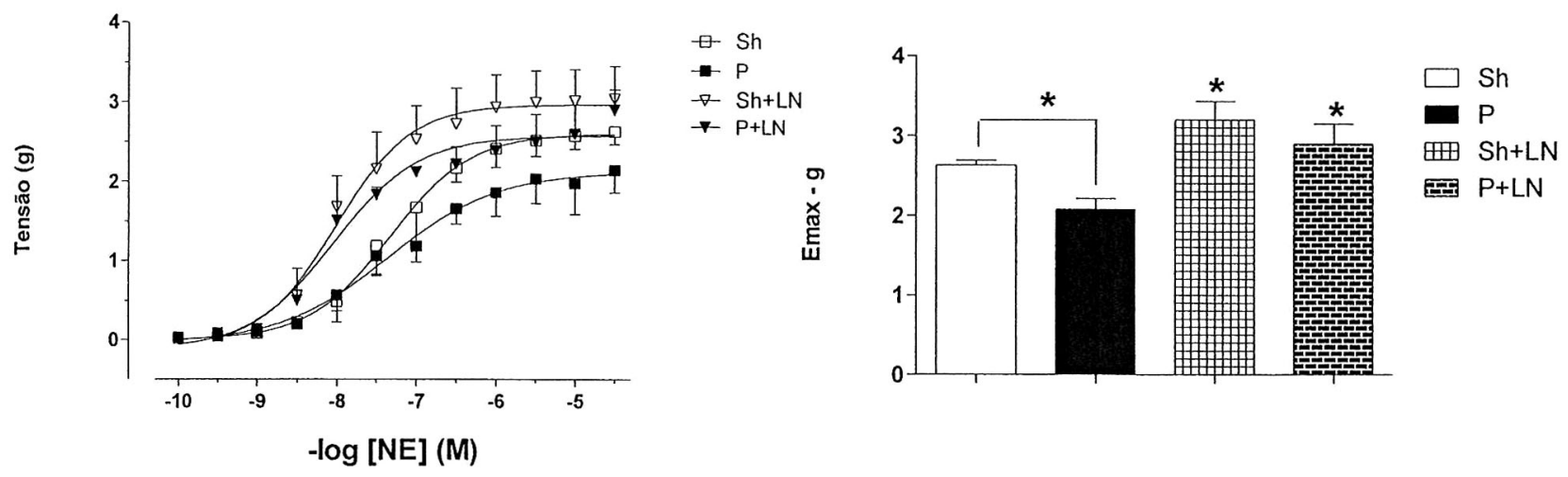

Painel A - curva concentração-resposta para a norepinefrina em anéis de aorta de animais sham ou com periodontite que receberam a adição de L-NAME. Painel B - tensão máxima (Emax) alcançada por anéis de aorta que receberam a adição de L-NAME de animais sham ou periodontite, em resposta a norepinefrina. ${ }^{*}=p<0,05$ comparado aos seus respectivos controles $(n=8)$.

FONTE: Muscará, 2010. Com permissão. 
Figura 4 - Efeito do tratamento in vitro com 1400W sobre a resposta pressora à norepinefrina em anéis de aorta de animais sham ou periodontite.
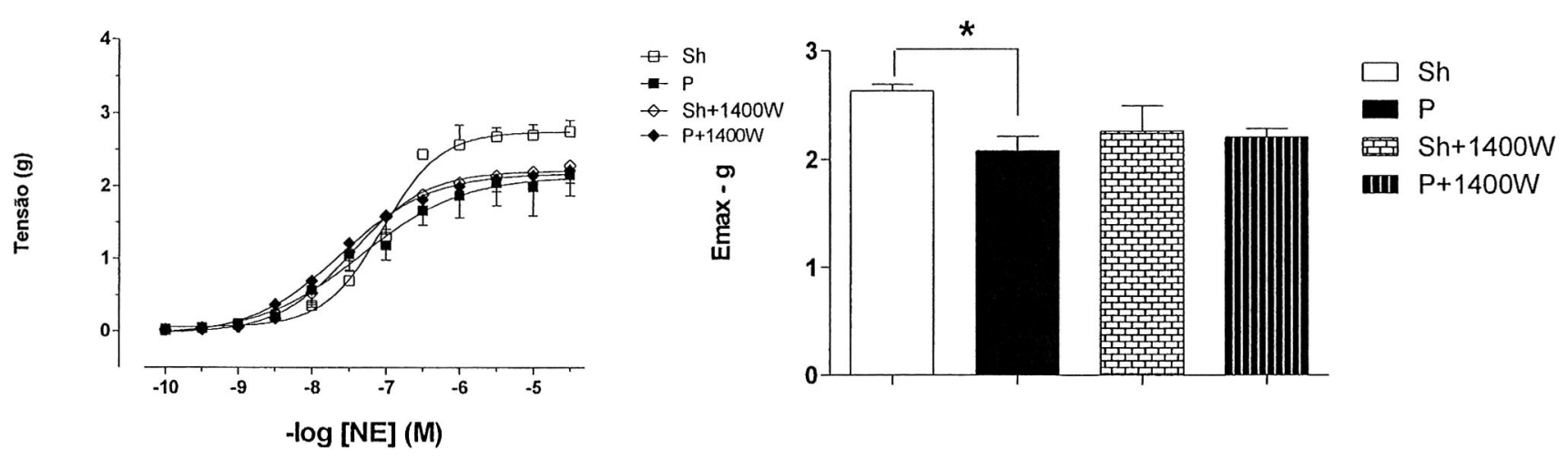

Painel A - curva concentração-resposta para a norepinefrina em anéis de aorta de animais sham ou com periodontite que receberam a adição de $1400 \mathrm{~W}$. Painel B - tensão máxima (Emax) alcançada por anéis de aorta que receberam a adição de $1400 \mathrm{~W}$ de animais sham ou periodontite, em resposta a norepinefrina. ${ }^{*}=p<0,05$ comparado ao controle $(n=8)$.

FONTE: Muscará, 2010. Com permissão.

Figura 5 - Efeito do tratamento in vitro com Indometacina (Indo) sobre a resposta pressora à norepinefrina em anéis de aorta de animais sham ou periodontite.
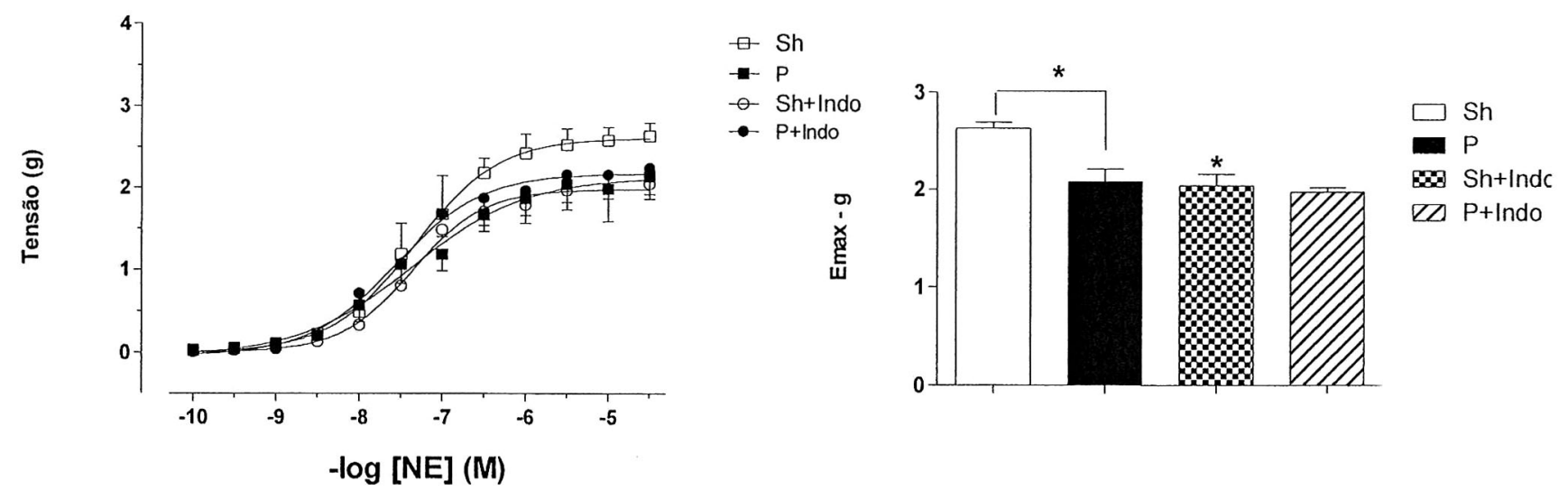

Painel A - curva concentração-resposta para a norepinefrina em anéis de aorta de animais sham ou com periodontite que receberam a adição de Indometacina. Painel B - tensão máxima (Emax) alcançada por anéis de aorta que receberam a adição de Indometacina de animais sham ou periodontite, em resposta a norepinefrina. ${ }^{*}=p<0,05$ comparado aos seus controles $(n=8)$.

FONTE: Muscará, 2010. Com permissão. 
Figura 6 - Efeito do tratamento in vitro com SC560 sobre a resposta pressora para norepinefrina em anéis de aorta de animais sham ou periodontite.
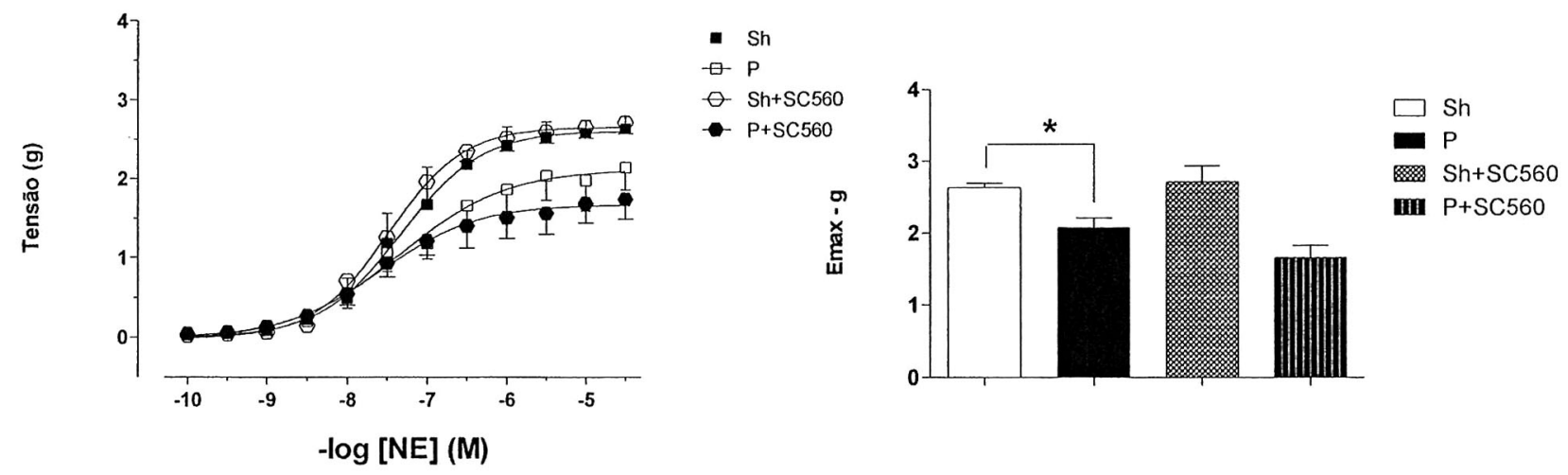

Painel A - curva concentração-resposta para a norepinefrina em anéis de aorta de animais sham ou com periodontite que receberam a adição de SC560. Painel B -tensão máxima (Emax) alcançada por anéis de aorta que receberam a adição SC560 de animais sham ou periodontite, em resposta a norepinefrina. ${ }^{*}=p<0,05$ comparado aos seus controles $(n=8)$. FONTE: Muscará, 2010. Com permissão.

Figura 7 - Efeito do tratamento in vitro com NS398 sobre a resposta pressora para norepinefrina em anéis de aorta de animais sham ou periodontite.
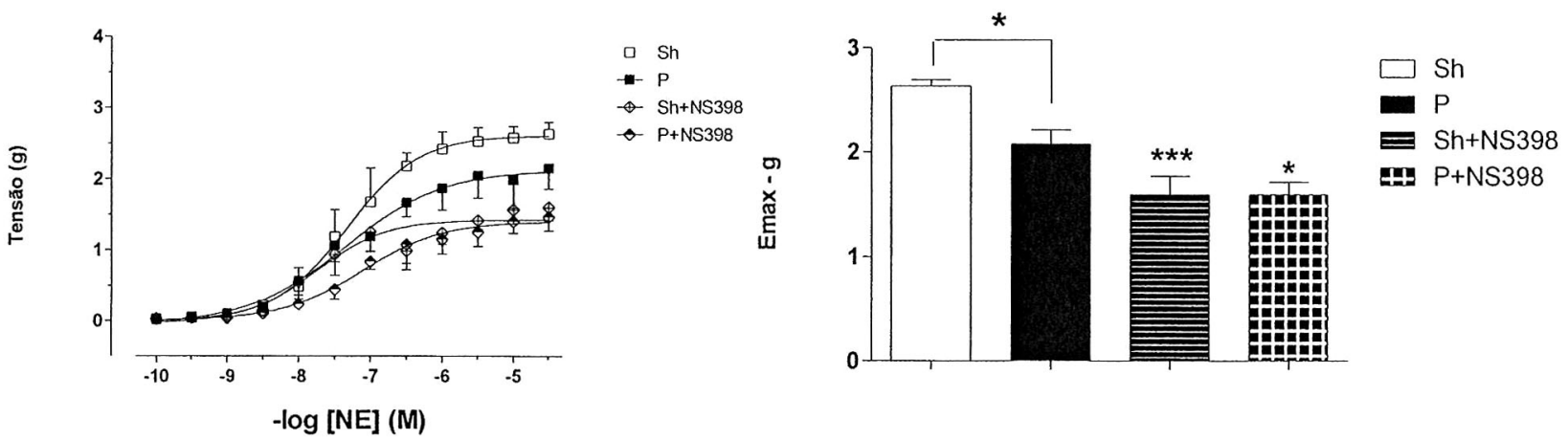

Painel A - curva concentração-resposta para a norepinefrina em anéis de aorta de animais sham ou com periodontite que receberam a adição de NS398. Painel B -tensão máxima (Emax) alcançada por anéis de aorta que receberam a adição NS398 de animais sham ou periodontite, em resposta a norepinefrina. ${ }^{*}=p<0,05$ comparado aos seus controles $(n=8)$. FONTE: Muscará, 2011. Com permissão. 
Figura 8 - Efeito do tratamento in vitro com L-NAME (LN) sobre a dilatação de anéis de aorta de animais sham ou com periodontite, em resposta a acetilcolina.
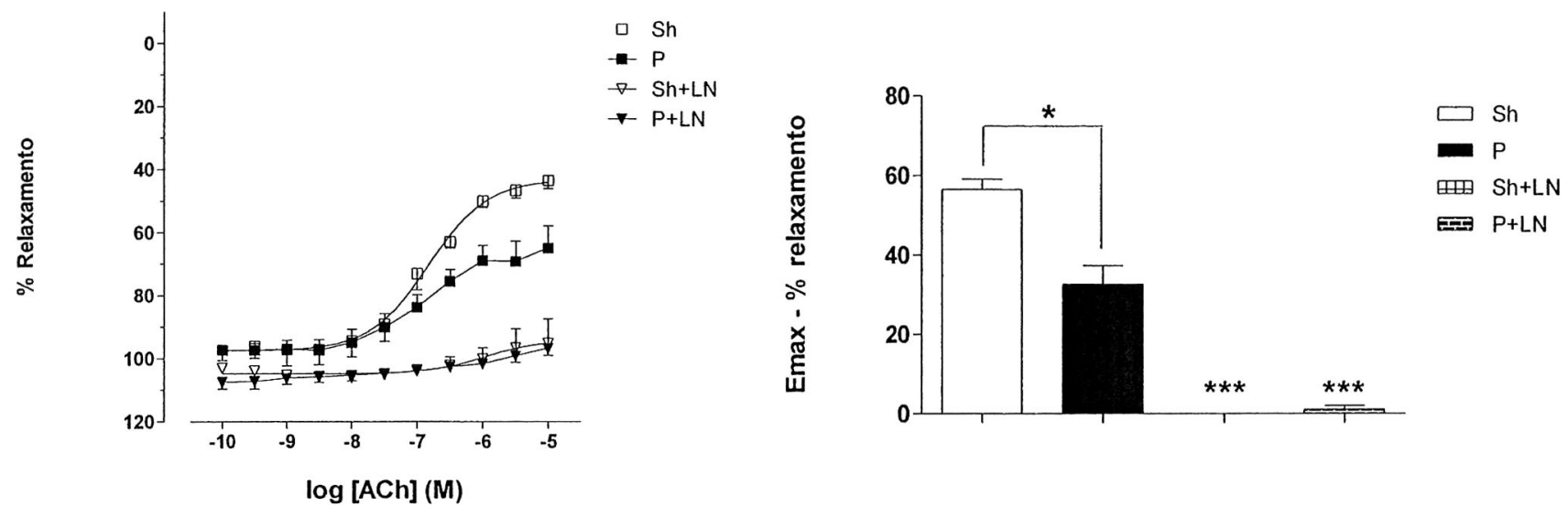

Painel A - curva concentração-resposta curva acetilcolina em anéis de aorta de animais sham ou com periodontite tratados com L-NAME. Painel B - tensão máxima (Emax) em percentagem obtida por anéis de aorta de animais sham ou com periodontite tratados com L-NAME, em resposta a acetilcolina. ${ }^{*}=p<0,05 e^{* * *}=p<0.001$ comparados aos seus controles $(n=8)$.

FONTE: Muscará, 2011. Com permissão

Figura 9 - Efeito do tratamento in vitro com 1400W sobre a dilatação de anéis de aorta de animais sham ou com periodontite, em resposta a acetilcolina.
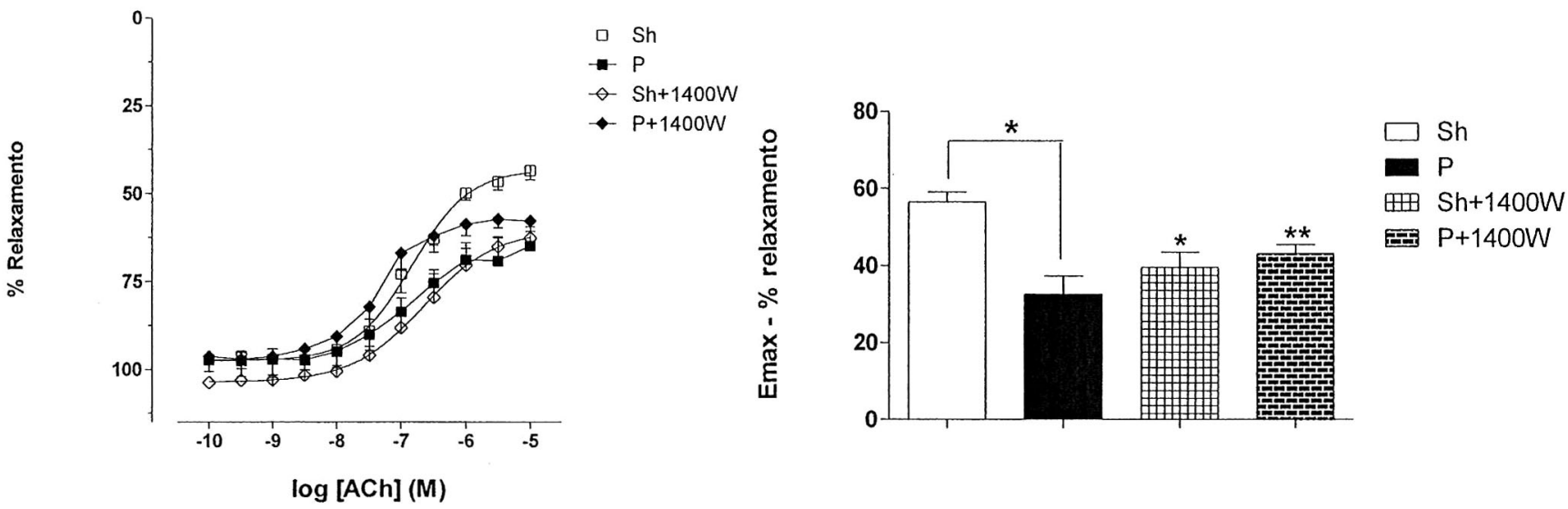

Painel A - curva concentração-resposta curva acetilcolina em anéis de aorta de animais sham ou com periodontite tratados com 1400W Painel B - tensão máxima (Emax) em percentagem obtida por anéis de aorta de animais sham ou com periodontite tratados com $1400 \mathrm{~W}$, em resposta a acetilcolina. ${ }^{*}=p<0,05 \mathrm{e}^{* *}=p<0.01$ comparados aos seus controles $(n=8)$.

FONTE: Muscará, 2011. Com permissão. 
Figura 10 - Efeito do tratamento in vitro com Indometacina (Indo) sobre a dilatação de anéis de aorta de animais sham ou com periodontite, em resposta a acetilcolina.
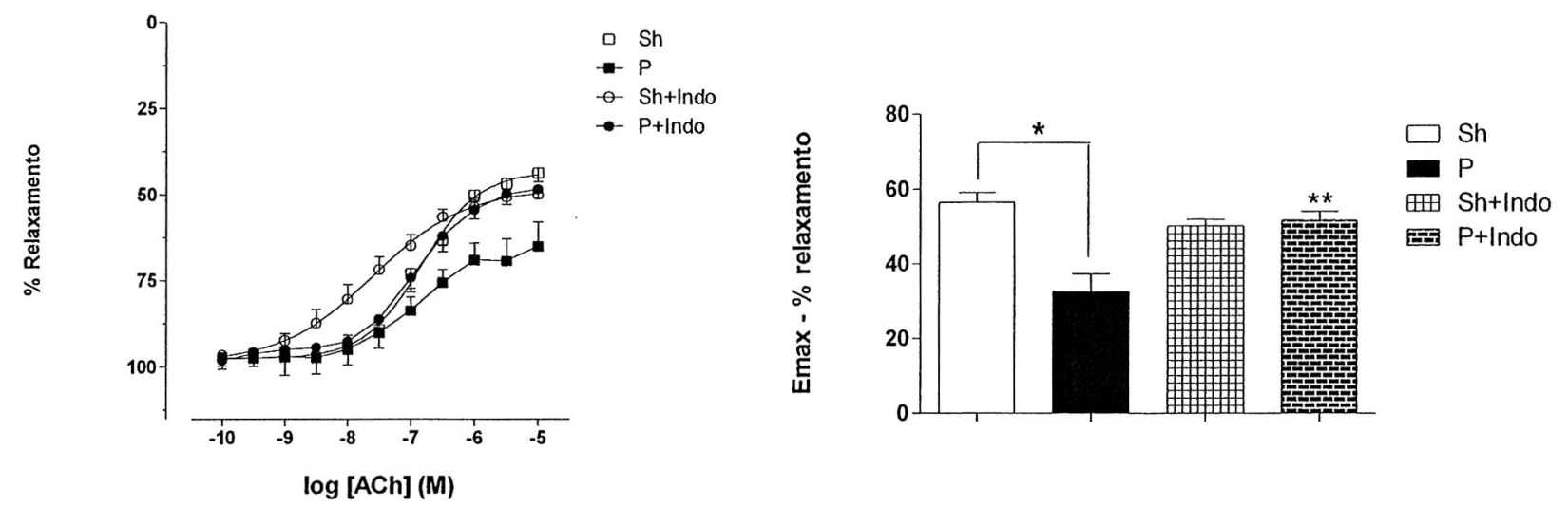

Painel A - curva concentração-resposta curva acetilcolina em anéis de aorta de animais sham ou com periodontite tratados com Indometacina. Painel B - tensão máxima (Emax) em percentagem obtida por anéis de aorta de animais sham ou com periodontite tratados com Indometacina, em resposta a acetilcolina. ${ }^{*}=p<0,05 e^{* *}=p<0.01$ comparados aos seus controles $(n=8)$.

FONTE: Muscará, 2010. Com permissão.

Figura 11 - Efeito do tratamento in vitro com SC560 sobre a dilatação de anéis de aorta de animais sham ou com periodontite, em resposta a acetilcolina.
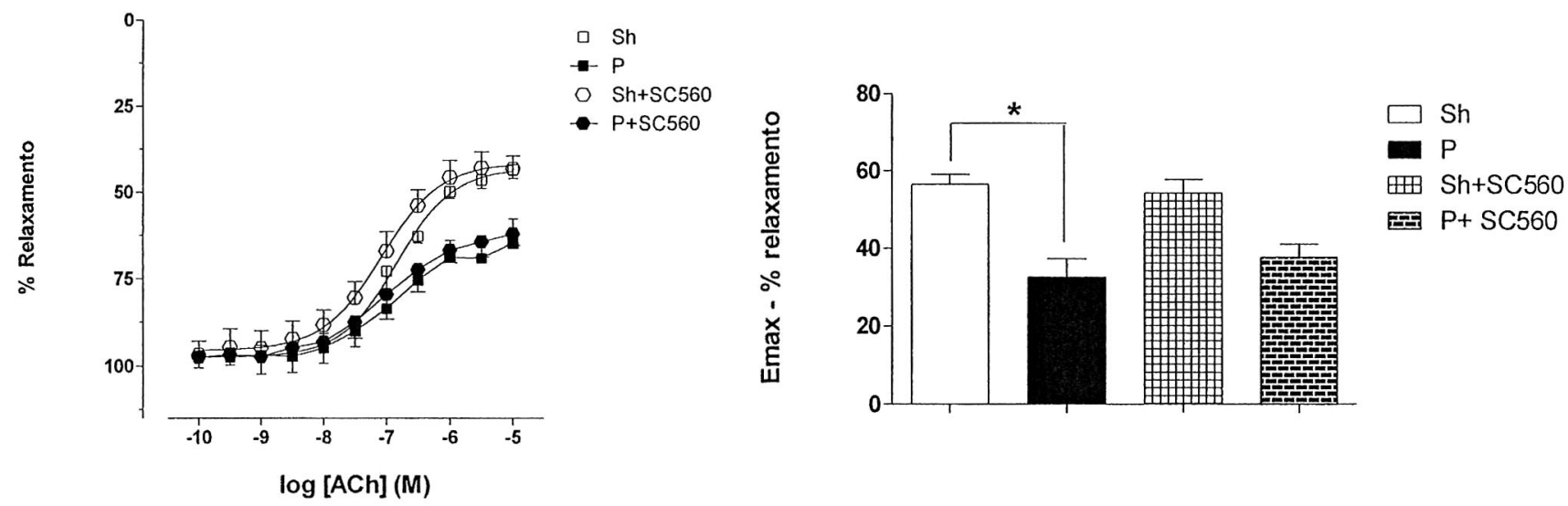

Painel A -curva concentração-resposta curva acetilcolina em anéis de aorta de animais sham ou com periodontite tratados com SC560. Painel B - tensão máxima (Emax) em percentagem obtida por anéis de aorta de animais sham ou com periodontite tratados com SC560, em resposta a acetilcolina. ${ }^{*}=p<0,05$ comparado ao controle $(n=8)$.

FONTE: Muscará, 2010. Com permissão. 
Figura 12 - Efeito do tratamento in vitro com NS398 sobre a dilatação de anéis de aorta de animais sham ou com periodontite, em resposta a acetilcolina.
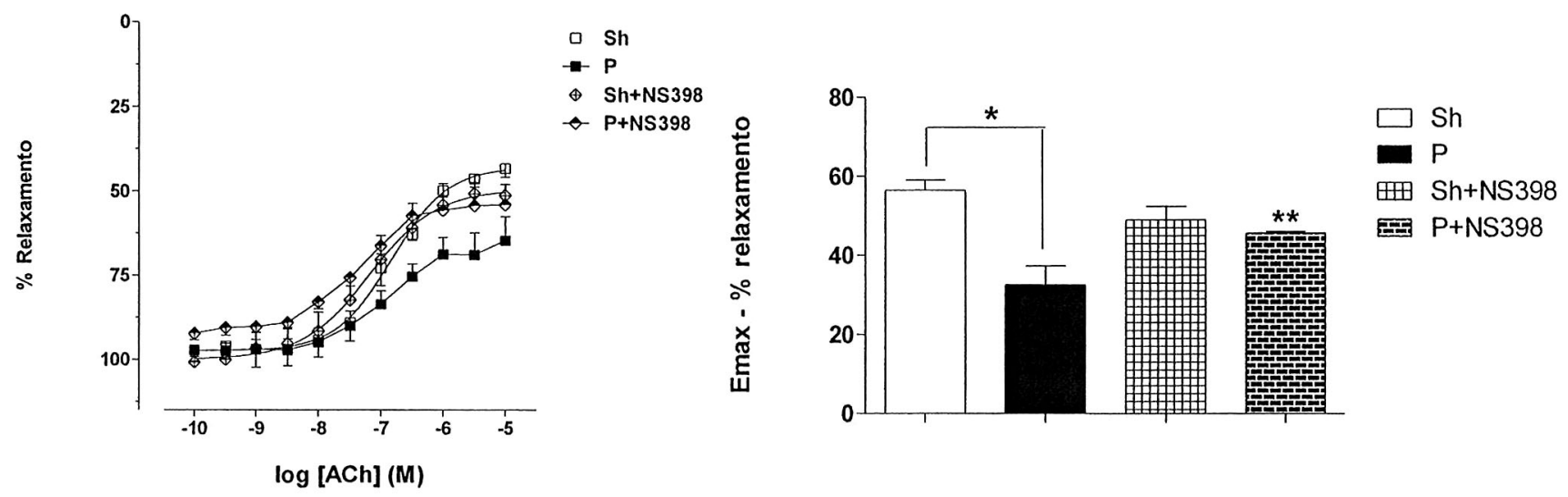

Painel A - curva concentração-resposta curva acetilcolina em anéis de aorta de animais sham ou com periodontite tratados com NS398. Painel B - tensão máxima (Emax) em percentagem obtida por anéis de aorta de animais sham ou com periodontite tratados com NS398, em resposta a acetilcolina. ${ }^{*}=p<0,05 e^{* *}=p<0.01$ comparados aos seus controles $(n=8)$.

FONTE: Muscará, 2010. Com permissão. 
Figura 13 - Efeito do tratamento in vivo com L-NAME (LN) sobre a contração de anéis de aorta de animais sham ou com periodontite, em resposta à norepinefrina.

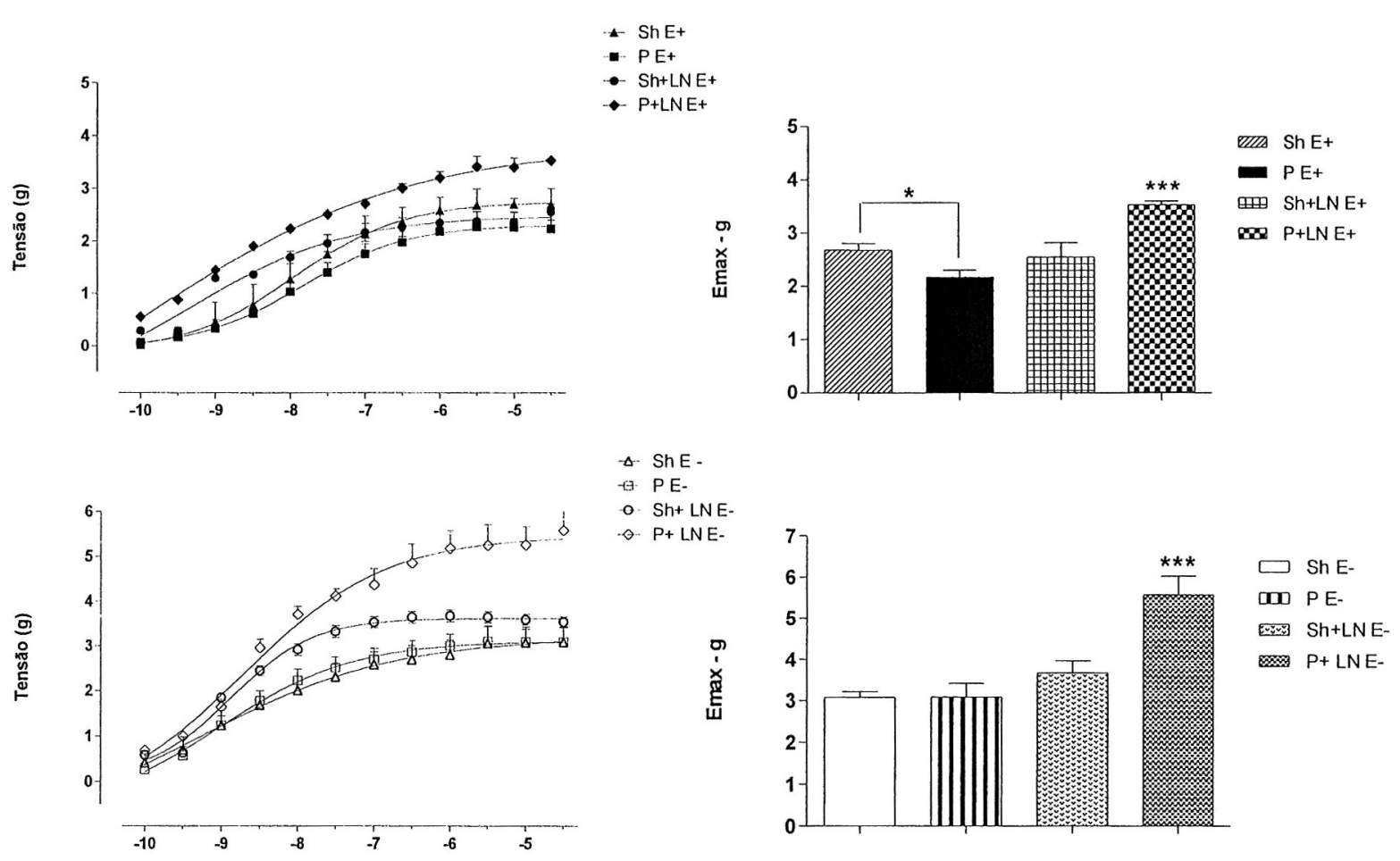

Painel A - curva concentração-resposta para a norepinefrina em anéis de aorta com endotélio de animais sham ou com periodontite tratados com L-NAME. Painel B - tensão máxima (Emax) em gramas obtidos por anéis da aorta com endotélio de animais sham ou com periodontite animais tratados com L-NAME, em resposta a norepinefrina. ${ }^{*}=\mathrm{P}<0,05 \mathrm{e}$ ${ }^{* * *}=p<0,001$ em comparação com o controle $(n=8)$. Painel C - curva concentraçãoresposta para a norepinefrina em anéis de aorta sem endotélio de animais sham ou com periodontite tratados com L-NAME. Painel D - tensão máxima (Emax) em gramas obtidos por anéis de aorta sem endotélio de animais sham ou com periodontite tratados com LNAME, em resposta a norepinefrina. ${ }^{* * *}=p<0,001$ em comparação com o controle $(n=8)$.

FONTE: Muscará, 2011. Com permissão. 
Figura 14 - Efeito do tratamento in vivo com Etoricoxib (Eto) sobre a contração de anéis de aorta de animais sham ou com periodontite, em resposta à norepinefrina.
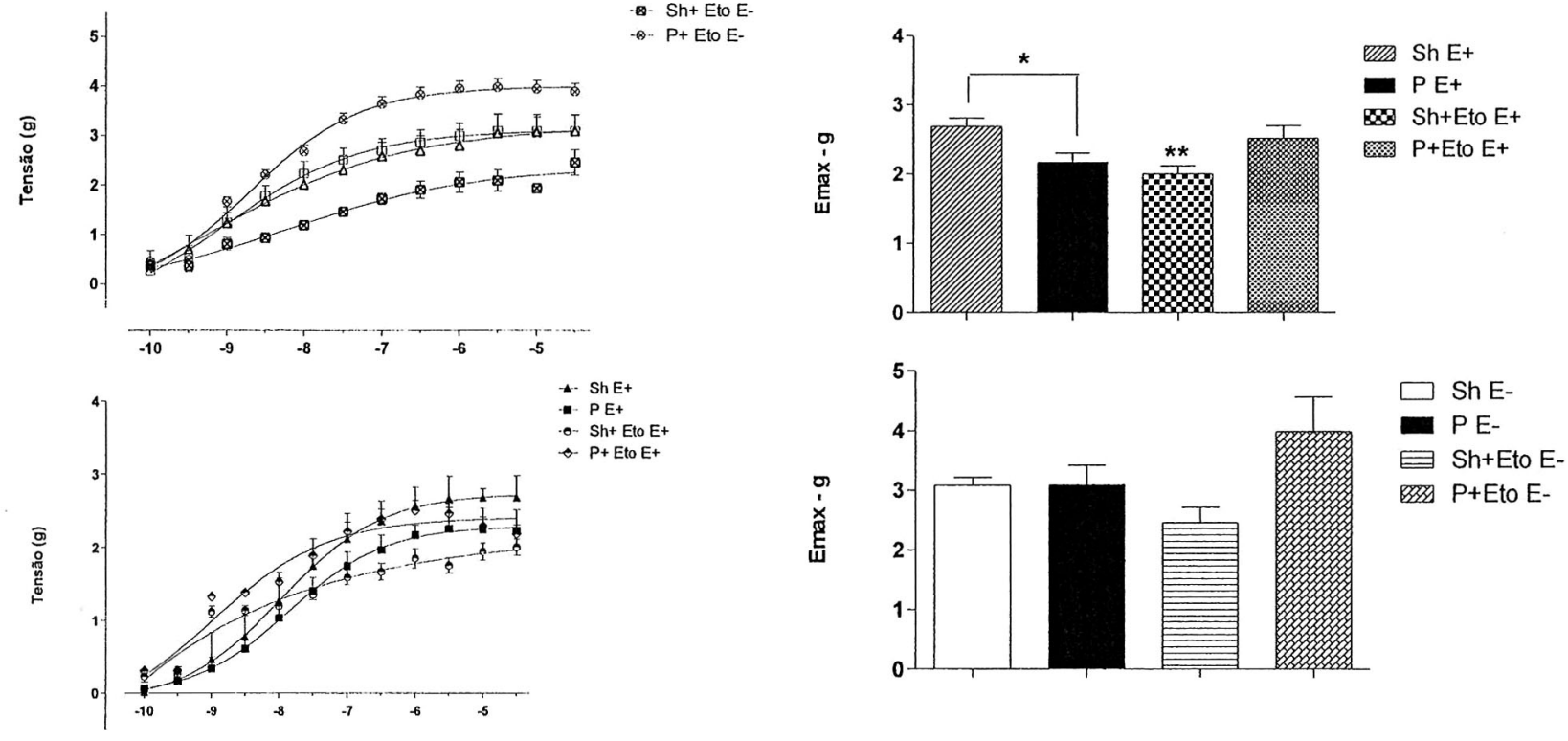

Painel A - curva concentração-resposta para a norepinefrina em anéis de aorta com endotélio de animais sham ou com periodontite tratados com Etoricoxib. Painel B - tensão máxima (Emax) em gramas obtidos por anéis da aorta com endotélio de animais sham ou com periodontite animais tratados comEtoricoxib, em resposta a norepinefrina. ${ }^{*}=P<0,05 \mathrm{e}$ ${ }^{* *}=p<0,01$ em comparação com o controle $(n=8)$. Painel $C$ - curva concentração-resposta para a norepinefrina em anéis de aorta sem endotélio de animais sham ou com periodontite tratados com Etoricoxib. Painel D - tensão máxima (Emax) em gramas obtidos por anéis de aorta sem endotélio de animais sham ou com periodontite tratados com Etoricoxib, em resposta à norepinefrina. $(n=8)$.

FONTE: Muscará, 2011. Com permissão. 
Figura 15 - Efeito do tratamento in vivo com L-NAME (LN) sobre a dilatação dos anéis de aorta de animais sham ou com periodontite periodontite em resposta a acetilcolina.
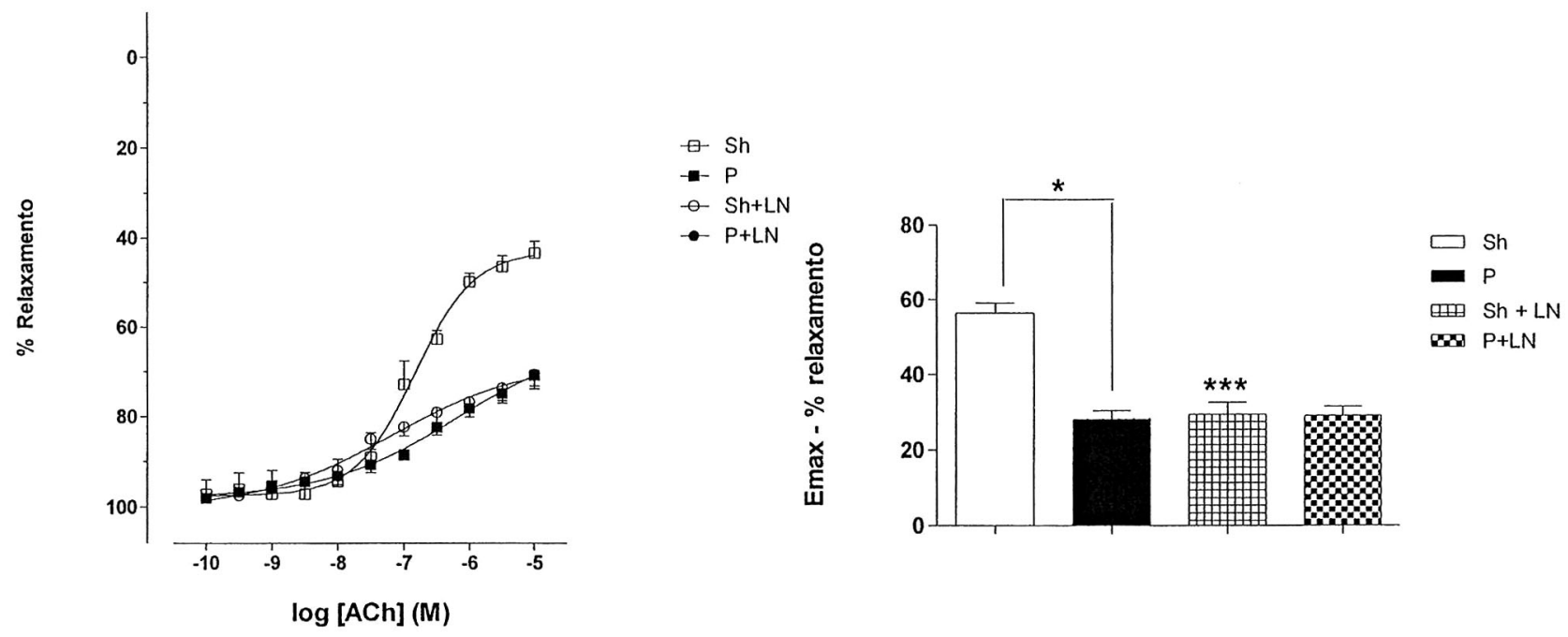

Painel A - curva concentração-resposta para acetilcolina em anéis de aorta de animais sham ou com periodontite tratados com L-NAME: Painel B - tensão máxima (Emax) em percentagem de relaxamento alcançado por anéis de aorta de animais sham ou com periodontite tratados com L-NAME, em resposta a acetilcolina. ${ }^{*}=p \quad<0,05$ e ${ }^{* * *}=p$ $<0,001$ em comparação com o controle $(n=8)$.

FONTE: Muscará, 2011. Com permissão.

Figura 16 - Efeito do tratamento in vivo com Etoricoxib (Eto) sobre a dilatação dos anéis de aorta de animais sham ou com periodontite periodontite em resposta a acetilcolina.
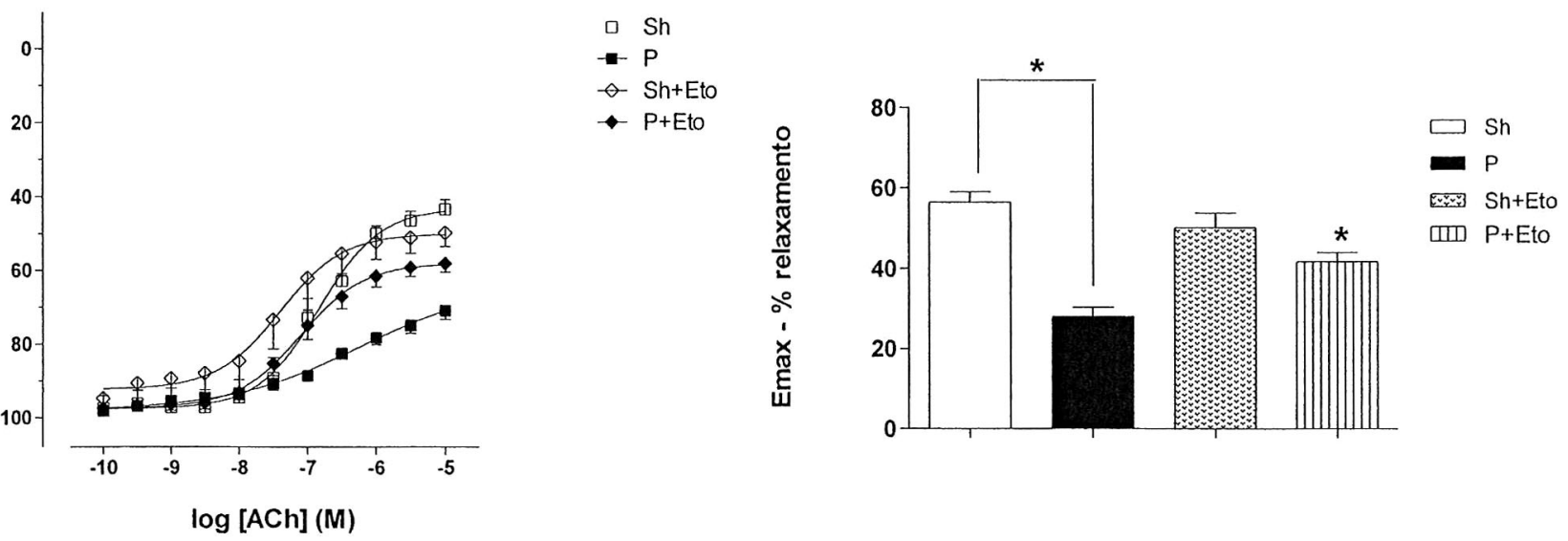

Painel A - Curva de concentração-resposta para os anéis de aorta de animais sham ou com periodontite tratados com Etoricoxib. Painel B - tensão máxima (Emax) em percentagem de relaxamento alcançado por anéis de aorta de animais sham ou com periodontite tratados com Etoricoxib, em resposta a acetilcolina. ${ }^{*}=p<0,05$ em comparação com o controle $(n=$ 8).

FONTE: Muscará, 2011. Com permissão. 
Figura 17 - Efeito da adição de $84 \mathrm{mM}$ de $\mathrm{KCl}$ sobre aorta de animais sham ou com periodontite tratados com L-NAME (LN) ou Etoricoxib (Eto) com ou sem endotélio.
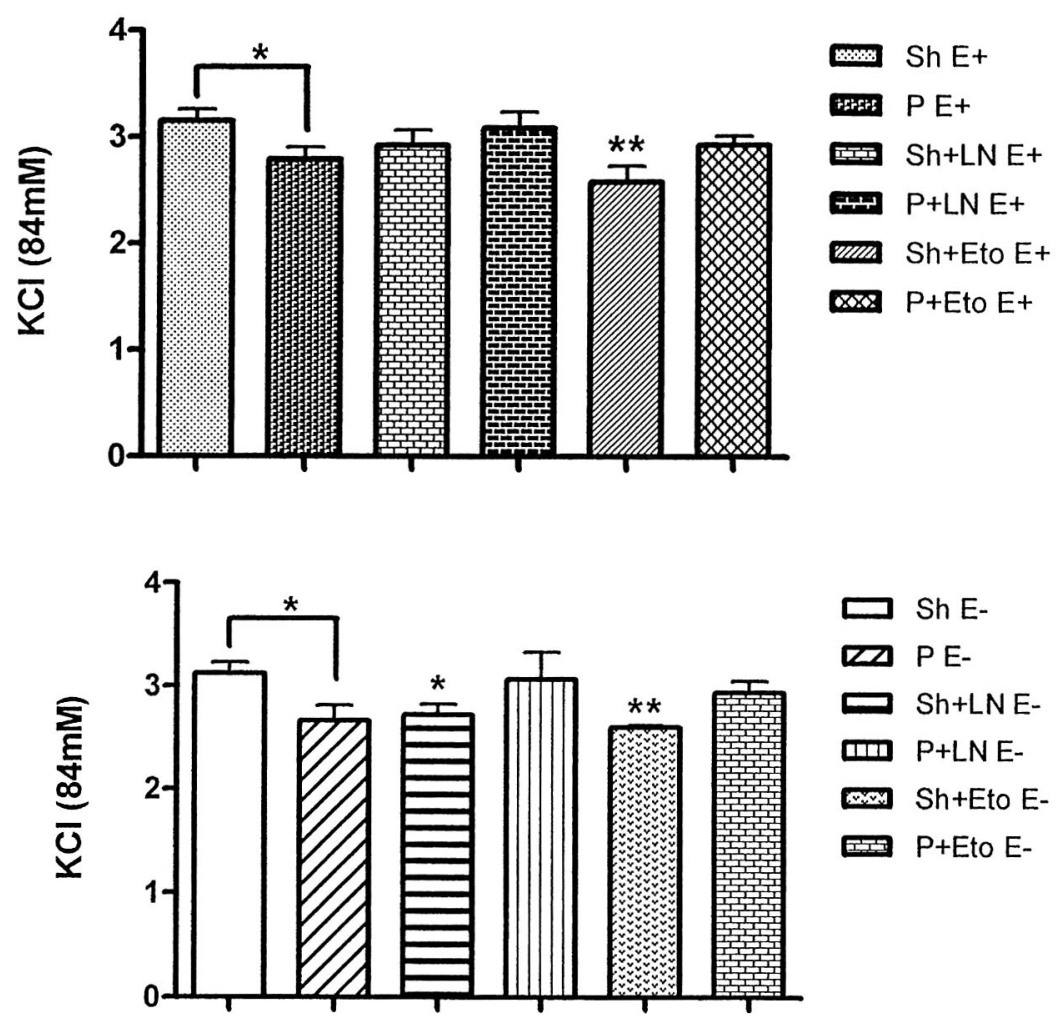

Painel A: efeito de indução de periodontite, o tratamento com L-NAME ou Etoricoxib sobre a contração mediada $\mathrm{KCl}$ em aortas com endotélio. ${ }^{*}=p<0,05 \mathrm{e}^{* *}=p<0,01$ vs. seu controle. Painel: efeito de indução de periodontite, o tratamento com L-NAME ou Etoricoxib sobre a contração mediada $\mathrm{KCl} \mathrm{em}$ aortas sem endotélio. ${ }^{*}=p<0,05$ e ${ }^{* *}=p<0,01$ versus seu controle, $\mathrm{n}=8$.

FONTE: Muscará, 2010. Com permissão. 
Figura 18 - Efeito do tratamento com L-NAME ou Etoricoxib sobre a pressão arterial (PA) de ratos com ou sem periodontite.

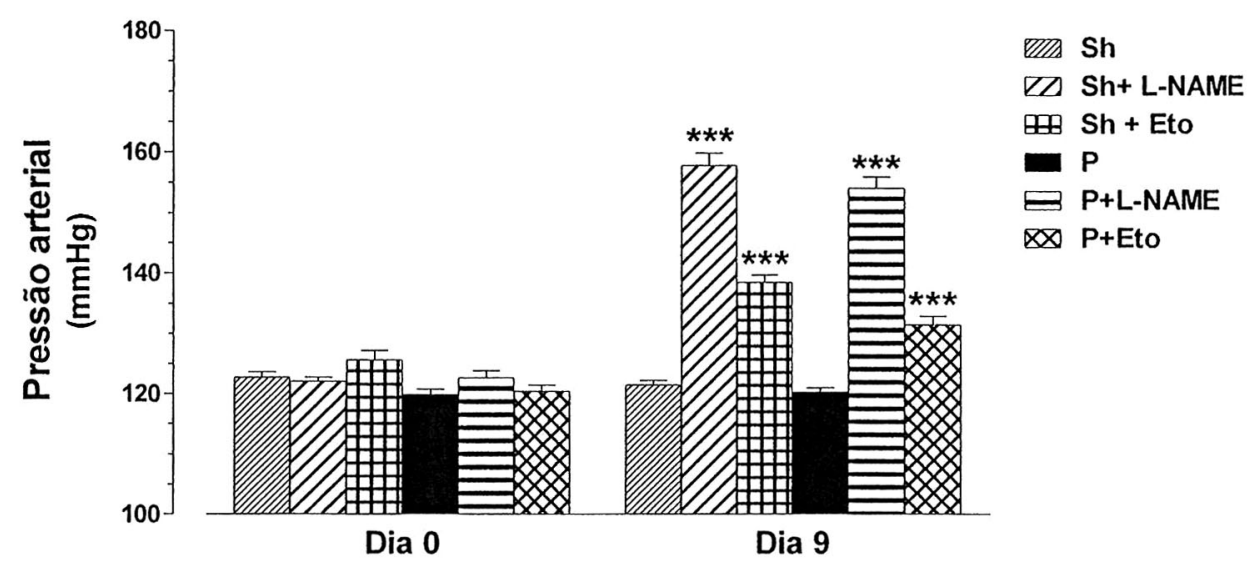

A pressão foi mensurada nos dias 0 e 9 após o início do tratamento dos ratos com L-NAME ou Etoricoxib (Eto). ${ }^{* *}=p<0.001$ vs. o respectivo valor de PA mensurado no dia 0 ( $n=$ 8).

FONTE: Muscará, 2011. Com permissão. 
Figura 19 - Efeito da indução de periodontite e tratamento com L-NAME ou Etoricoxib sobre a expressão de mRNA para COX-1 em amostras de aorta de rato.

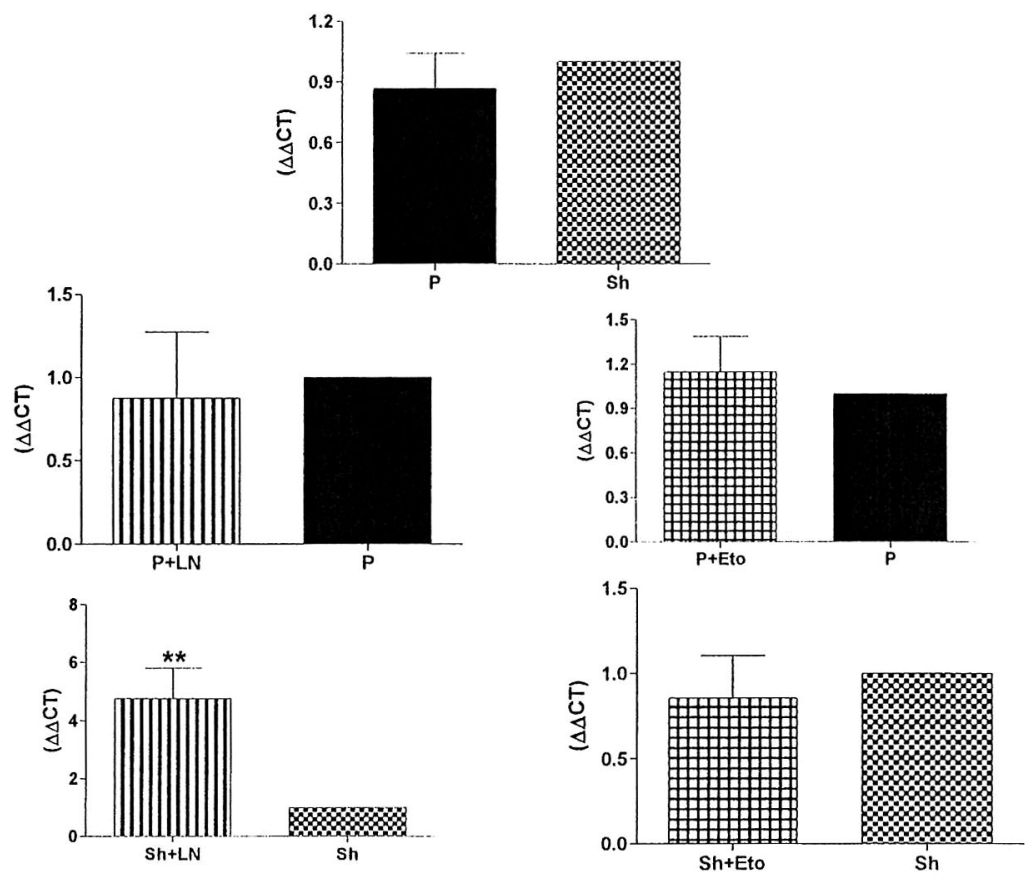

Painel A - Efeito da indução de periodontite sobre a expressão de mRNA para COX-1. Painel B -. Efeito do tratamento com L-NAME sobre a expressão de mRNA para COX-1 em amostras de animais com periodontite. Painel C - Efeito do tratamento com Etoricoxib sobre a expressão de mRNA para COX-1 em amostras de animais com periodontite. Painel D Efeito do tratamento com L-NAME sobre a expressão de mRNA para COX-1 em amostras de animais sham. Painel $E$ - Efeito do tratamento com Etoricoxib sobre a expressão de mRNA para COX-1 em amostras de animais sham ${ }^{* *}=p<0.01$ vs. controle. $n=8$. FONTE: Muscará, 2011. Com permissão. 
Figura 20 - Efeito da indução de periodontite e tratamento com L-NAME ou Etoricoxib sobre a expressão de mRNA para COX-2 em amostras de aorta de rato.

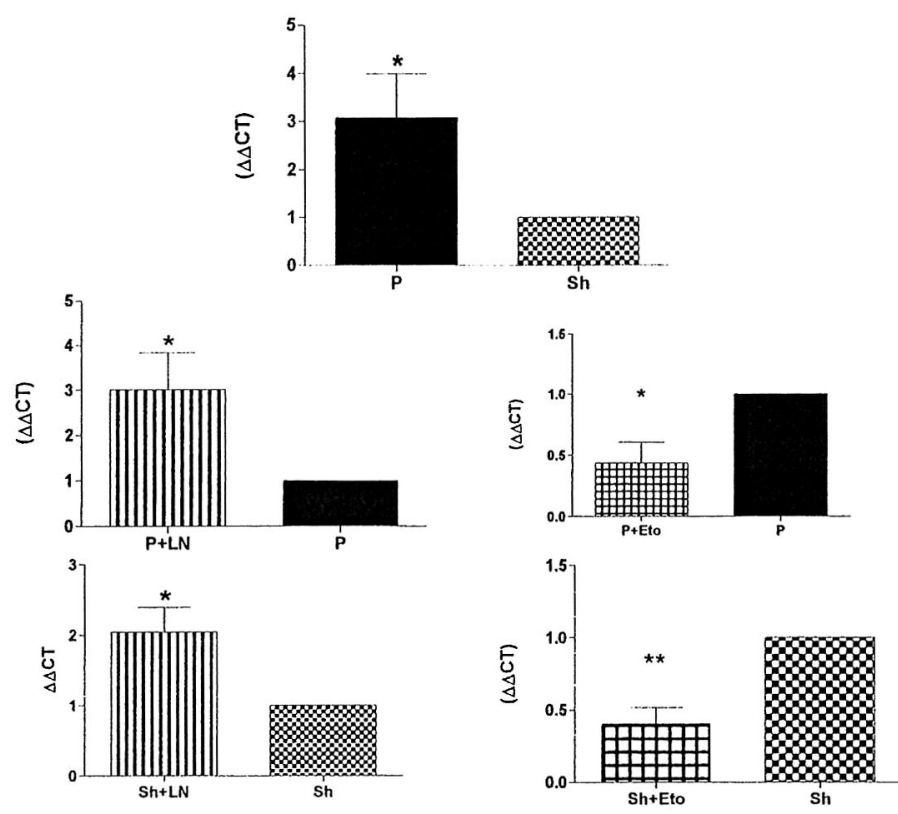

Painel A - Efeito da indução de periodontite sobre a expressão de mRNA para COX-2. Painel B -. Efeito do tratamento com L-NAME sobre a expressão de mRNA para COX-2 em amostras de animais com periodontite. Painel C - Efeito do tratamento com Etoricoxib sobre a expressão de mRNA para COX-2 em amostras de animais com periodontite. Painel D -. Efeito do tratamento com L-NAME sobre a expressão de mRNA para COX-2 em amostras de animais sham. Painel $E$ - Efeito do tratamento com Etoricoxib sobre a expressão de mRNA para COX-2 em amostras de animais sham ${ }^{*}=p<0,05 e^{* *}=p<0.01$ vs. controle. $n=$ 8.

FONTE: Muscará, 2011. Com permissão. 
Figura 21 - Efeito da indução de periodontite e tratamento com L-NAME ou Etoricoxib sobre a expressão de mRNA para eNOS em amostras de aorta de rato.

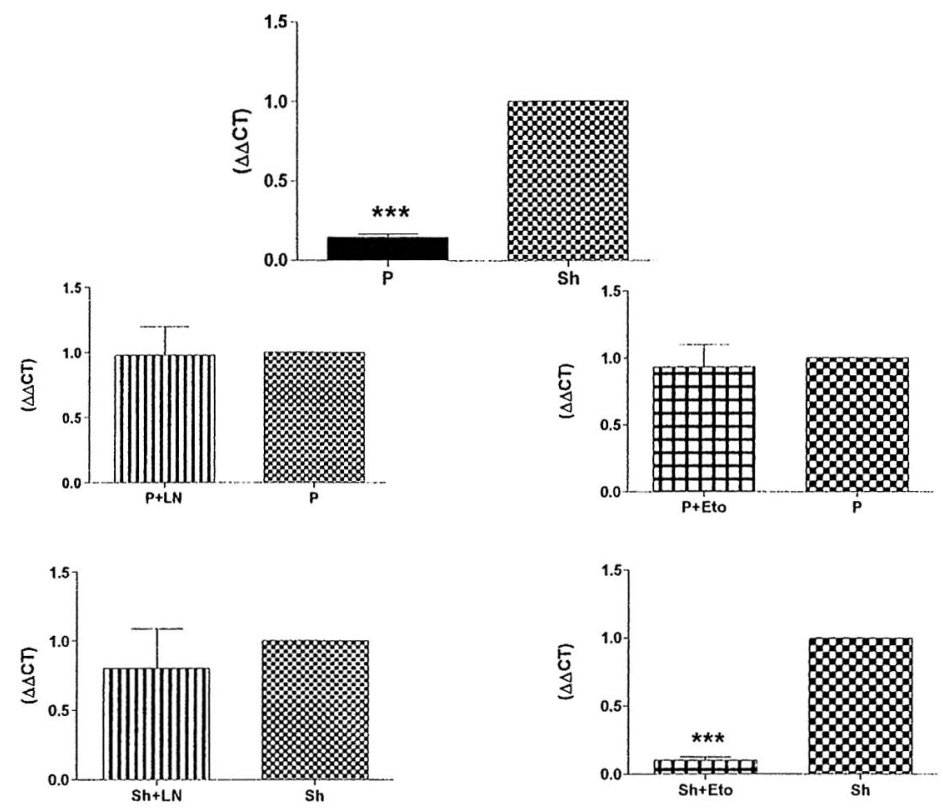

Painel A - Efeito da indução de periodontite sobre a expressão de mRNA para eNOS. Painel B -. Efeito do tratamento com L-NAME sobre a expressão de mRNA para eNOS em amostras de animais com periodontite. Painel C - Efeito do tratamento com Etoricoxib sobre a expressão de mRNA para eNOS em amostras de animais com periodontite. Painel D -. Efeito do tratamento com L-NAME sobre a expressão de mRNA para eNOS em amostras de animais sham. Painel E- Efeito do tratamento com Etoricoxib sobre a expressão de mRNA para eNOS em amostras de animais sham ${ }^{\star \star \star}=p<0.01$ vs. controle. $(n=8$.).

FONTE: Muscará, 2011. Com permissão. 
Figura 22 - Efeito da indução de periodontite e tratamento com L-NAME ou Etoricoxib sobre a expressão de mRNA para iNOS em amostras de aorta de rato.
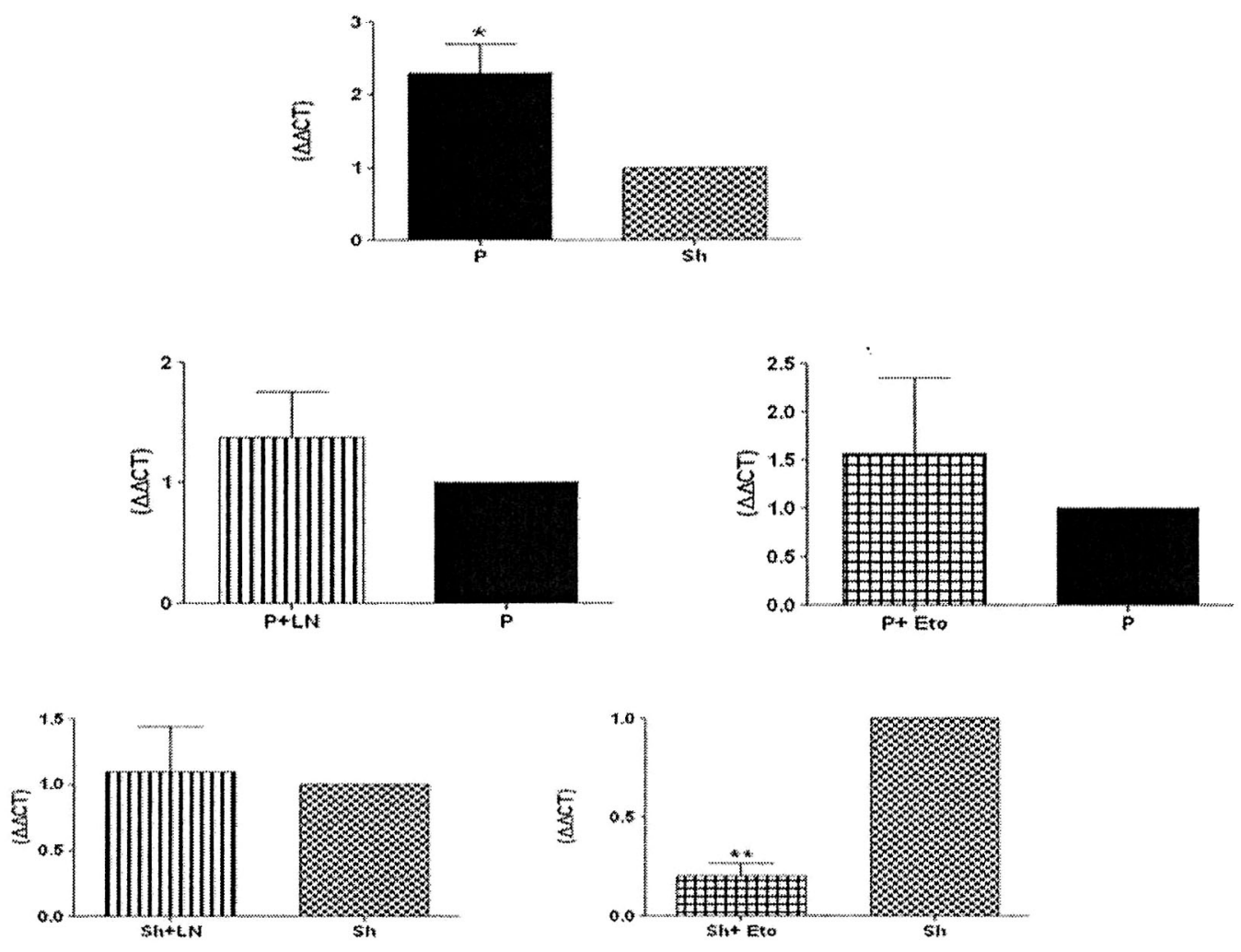

Painel A - Efeito da indução de periodontite sobre a expressão de mRNA para iNOS. Painel B - Efeito do tratamento com L-NAME sobre a expressão de mRNA para iNOS em amostras de animais com periodontite. Painel $\mathrm{C}$ - Efeito do tratamento com Etoricoxib sobre a expressão de mRNA para iNOS em amostras de animais com periodontite. Painel D -. Efeito do tratamento com L- NAME sobre a expressão de mRNA para iNOS em amostras de animais sham. Painel $E$ - Efeito do tratamento com Etoricoxib sobre a expressão de mRNA para iNOS em amostras de animais sham ${ }^{*}=p<0,05 e^{* *}=p<0.01$ vs. controle. $n=$ 8.

FONTE: Muscará, 2011. Com permissão. 
Figura 23 - Expressão proteica de COX-2 protein em amostras de aorta de animais com periodontite e sham.

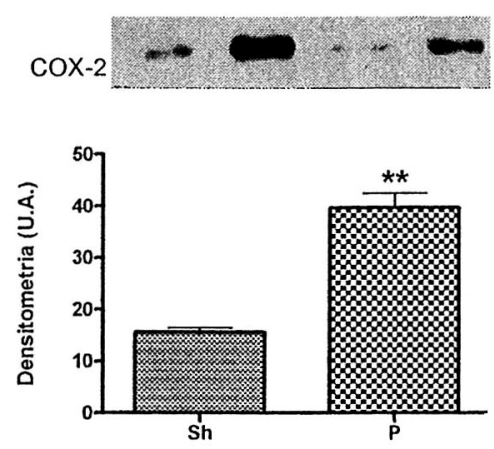

Western blot para COX-2 em amostras de aorta de animais sham e com periodontite. U.A. $=$ unidades arbitrárias. ${ }^{*}=p<0.01, n=5$.

FONTE: Muscará, 2011. Com permissão. 


\section{DISCUSSÃo}

Em tecidos vasculares, algumas citocinas ou componentes da parede celular bacteriana, como por exemplo o lipopolissacarídeo (LPS) contribuem para o aumento da expressão de iNOS (GODFREY et al., 2011). É geralmente aceito que, nesta situação, o NO contribui para a diminuição da resposta vascular contrátil através da ativação da guanosina 3 ': 5'-monofosfato cíclico (GMP cíclico) / GMP cíclico-dependente via da proteína quinase (STOCLET et al., 1993), conduzindo a uma diminuição na concentração de cálcio intracelular livre disponível para a contração (SCHMIDT et al., 1993).

Estudos mostram que o óxido nítrico (HERRERA et al., 2011) tem um papel fundamental no curso da periodontite induzida pela ligadura em ratos. $O$ tratamento com L-NAME ou aminoguanidina (inibidor de iNOS) diminui a perda óssea secundária à periodontite, através da diminuição da quantidade de osteoclastos, células responsáveis pela reabsorção óssea. Por outro lado, concentrações locais elevadas de $\mathrm{NO}$ e seus derivados oxidativos como o peroxinitrito (ONOO-) são comprovadamente tóxicas para as células eucarióticas, bem como para os micróbios (GYURKO et al., 2003). Assim, o NO é reconhecido como uma molécula com efeito dual na defesa do hospedeiro.

Uma das principais e mais estudadas bactérias envolvidas na doença periodontal, Porphiromonas gingivalis, comprovadamente induz a expressão de iNOS em fibroblastos gengivais, células inflamatórias, e queratinócitos basais (KENDALL et al., 2000), estimula a liberação de NO por macrófagos (SHAPIRA et al., 1998), e induz a expressão do IFN- $\gamma$, citocina que induz a expressão de iNOS e assim causa um aumento da liberação de NO (OGAWA et al., 1994).

Prostanóides, principalmente derivados de COX-2 também têm um papel importante na progressão da doença periodontal, e tratamento de ratos com Etoricoxib, um inibidor específico de COX-2, provoca uma diminuição da perda óssea causada pela periodontite (HOULZHAUSEN et al., 2005). Prostaglandina $E_{2}$, um dos produtos derivados da COX-2 e também da COX-1 estimula a formação de osteoclastos (KANEKO et al., 2007).

Efeitos à distância da periodontite são provavelmente causados por bactérias ou seus produtos, bem como citocinas do hospedeiro que atingem a corrente sanguínea e causam efeitos semelhantes em outros locais à distância, portanto, NO 
e prostanóides produzidos principalmente por COX-2 podem ter participação nestes efeitos.

A contração reduzida das aortas de animais com periodontite pode estar relacionada a um aumento da produção de NO. A inibição não específica de produção de NO, por tratamento in vivo com L-NAME aumentou a contração à norepinefrina nesses animais - este fenômeno não ocorreu em animais sham apoiando esta teoria. Além disso, a expressão do mRNA para iNOS, a isoforma induzível da NOS que produz NO durante períodos mais longos e, portanto, em quantidades maiores do que as isoformas constitutivas é aumentada nestes animais. A inibição específica da iNOS por tratamento in vitro com $1400 \mathrm{~W}$ no entanto não teve efeito sobre a contração mediada pela norepinefrina.

No que diz respeito à participação de isoformas de COX, aparentemente a COX-1 não tem efeito neste quadro, embora haja uma forte tendência à diminuição da resposta contrátil à norepinefrina com o tratamento in vitro com SC560. Tratamento in vitro com NS398, um inibidor específico de COX-2 causou uma diminuição da resposta contrátil à noradrenalina em ambos os grupos, assim podese sugerir que a produção da enzima COX-2 esteja voltada para espécies vasoconstritoras (tais como TXA2). Curiosamente, o bloqueio de ambas as isoformas não tem qualquer efeito aditivo (tratamento com indometacina).

Tanto o tratamento in vivo com Etoricoxib quanto o tratamento in vitro com NS398 tiveram o mesmo efeito na resposta contrátil à norepinefrina em aortas de animais sham. Já em animais com periodontite apenas o tratamento com NS398 teve efeito sobre a resposta contrátil, causando diminuição da resposta.

Aparentemente, em animais sham a enzima COX-2 produz maior quantidade de mediadores vasoconstritores, uma vez que a sua inibição por tratamento com Etoricoxib provoca diminuição da resposta contrátil à norepinefrina. $\mathrm{O}$ tratamento com L-NAME, no entanto não teve efeito sobre a contração neste grupo. Portanto, sugerimos que ao contrário do que acontece com a pressão sanguínea, que é controlada principalmente por vasos de pequeno diâmetro, a inibição da isoforma COX-2 presente nos vasos maiores, tais como a aorta, provoca uma diminuição na produção de eicosanóides vasoconstritores.

Além disso, os resultados mostraram que o efeito contrátil de $\mathrm{KCl}$ é menor nos animais com periodontite, tanto na presença como na ausência de endotélio. Este resultado sugere que há alterações no músculo liso vascular, nestes animais, de 
modo que a menor contração à norepinefrina também pode ocorrer devido a uma insuficiência de resposta do músculo liso, bem como no endotélio. Estudos (PIEPOT et al., 2002) mostram que a exposição a LPS diminui a resposta despolarizante da aortas de ratos ao $\mathrm{KCl}$, e o autor utilizou uma maior concentração de $\mathrm{KCl}$ do que o utilizado no presente estudo (125 mM).

Em um modelo mais grave de infecção, a sepse, ocorre hipotensão generalizada, apesar da quantidade de catecolaminas produzidas (PARRILLO, 1993). Este fenômeno pode sèr explicado pela quantidade de NO gerado principalmente por iNOS (MONCADA et al., 1991). Também, pesquisas atuais mostram que em modelos animais de sepse há uma diminuição da expressão do receptor alfa-1, através do qual a norepinefrina exerce a sua ação no músculo liso vascular (BUCHER et al., 2003). Recentemente, foi mostrado que o $\mathrm{NF}_{-\kappa} \mathrm{B}$ (fator nuclear $-\kappa B$, um fator de transcrição pró-inflamatória) e interleucina-1 (IL-1) são também responsáveis pela diminuição da expressão de receptores $\alpha 1$ em um modelo de sepse em ratos (SCHMIDT et al., 2009).

Curiosamente, em animais com periodontite, o tratamento com L- NAME teve o mesmo efeito in vivo do que in vitro, mas o tratamento in vitro com um inibidor de COX-2 diminuiu ainda mais a contração, o que não aconteceu após o tratamento in vivo. Sugere-se que após 10 dias de tratamento com Etoricoxib estes animais desenvolveram uma adaptação à falta de COX-2.

No que diz respeito ao relaxamento, o tratamento in vivo e in vitro com L-NAME também teve o mesmo efeito sobre a reatividade vascular para a acetilcolina em animais sham, enquanto que apenas o tratamento in vitro com L-NAME causou uma diminuição do relaxamento, em animais com periodontite. Podemos notar também que em animais sham, a inibição específica da iNOS causou uma diminuição no relaxamento, o que leva a pensar que esta enzima tem um papel na reatividade vascular, mesmo na ausência de inflamação. Em animais com periodontite verificouse que os tratamentos in vivo e in vitro com um inibidor específico de COX-2 resultaram em respostas semelhantes, a melhoria do relaxamento mediado pela acetilcolina, resultado que também ocorreu após a inibição específica de iNOS através da adição de $1400 \mathrm{~W}$.

Ao contrário do que acontece com a contração, em animais com periodontite, a diminuição do relaxamento mediado por acetilcolina parece estar relacionada com 
as espécies produzidas por enzima COX-2, uma vez que a inibição específica da presente isoforma restaurou o relaxamento vascular nestes animais. Como apontado anteriormente, o relaxamento mediado pela acetilcolina é dependente do endotélio, mais precisamente da enzima eNOS. Por conseguinte, a diminuição da expressão da enzima eNOS pode estar contribuindo para a diminuição da resposta à acetilcolina observada..

O tratamento com L-NAME provoca um aumento no mRNA para COX-1 em aorta de animais sham, e de mRNA de COX-2 em ambos os grupos. Estudos mostram uma interação positiva entre prostaglandina $E_{2}$ e nNOS no cérebro, no periodo perinatal (DUMONT et al., 1998). PGE 2 endógena diminui a indução iNOS por IL-1 $\beta$, sendo que este efeito não é mediado pela ativação da adenilato ciclase (TETSUKA et al., 1994). Outro estudo mostra que o óxido nítrico estimula a atividade desta isoenzima possivelmente através do componente heme que se liga ao sítio ativo da enzima COX.

A interação estreita entre as vias da NOS e da COX é evidente. O tratamento com Etoricoxib causou uma diminuição da expressão de mRNA de COX-2, um resultado inesperado uma vez que a sua inibição é principalmente enzimática. O celecoxib, outro inibidor de COX-2 faz com que ocorra uma pequena diminuição na expressão de mRNA para COX-2 (LI et al., 2009), enquanto rofecoxib, não causa qualquer efeito sobre a expressão de mRNA para COX-2 (ALMENDINGEN et al., 2010).

Como os resultados mostram, a periodontite parece ter influência sobre os vasos de maior calibre em vez de pequenos. Esta afirmação pode ser feita porque o protocolo de indução de periodontite não causou qualquer modificação na pressão arterial. O aumento da pressão arterial causado pelo tratamento com o inibidor de NOS, L-NAME, era previsível já que este composto, assim como outros análogos da L-arginina, é utilizado em modelos animais de hipertensão secundária à disfunção endotelial (MUSCARÁ et al., 1998; RIBEIRO et al., 1992). O aumento da pressão arterial causado pelo tratamento de ratos com inibidores de COX-2, demonstrado originalmente por Muscará et al. (2000) em ratos tratados com celecoxibe (10 $\mathrm{mg} / \mathrm{kg}$ ), também foi mostrado por outros autores empregando Etoricoxibe (CHAN et al., 2009).

Os prostanóides (prostaglandinas, tromboxanas e prostaciclina) são a principal classe de eicosanóides vasoativos. Existe evidência considerável de que a 
prostaciclina juntamente com o NO (ambos de origem endotelial), apresentem importante papel na regulação do tônus vascular e da pressão arterial, seja causando efeitos vasodilatadores de forma direta ou modulando as ações de outros mediadores vasoativos, tais como angiotensina II, as catecolaminas, endotelina e arginina-vasopressina (CHAN; CERVONI, 1986; SHEPHERD; KATUSIC, 1991). Em contraste, o prostanóide vasoconstritor tromboxano A2 (TXA $)$ é produzido principalmente pelas plaquetas, e em quantidades bem menores por alguns vasos sistêmicos (SMITH, 1986). Acredita-se que o balanço entre a produção de $\mathrm{TXA}_{2}$ em plaquetas através da enzima COX-1 e a prostaciclina (PGI2) produzida pela COX-2 também seja importante para a manutenção do tônus vascular, pressão arterial e ativação de plaquetas (SELLERS; STALLONE, 2008). Assim, a inibição seletiva da COX-2 endotelial pelo Etoricoxib poderia causar o rompimento deste balanço a favor da produção de TXA $_{2}$ (CHAN; CERVONI, 1986). Esses fatos podem explicar o aumento da pressão arterial observado nos animais tratados com este antiinflamatório, assim como os efeitos cardiovasculares adversos que acabaram resultando na retirada destes compostos das prateleiras de venda livre nas farmácias (FAUNCE; TOWNSEND; MCEWAN, 2010). Além disso, a inibição da COX-2 da medula renal pode levar a retenção de sal e água, e redução da taxa de filtração glomerular, o que somado às conseqüências vasculares da inibição da COX-2 resulta em claro impacto desfavorável ao controle da pressão arterial (CHAN et al., 2009). 


\section{CONCLUSÕES}

Podemos concluiir que a periodontite induzida por ligadura causa importantes modificações em músculo liso e endotélio na aorta de ratos. Estas modificações levam estes vasos a terem resposta contrátil mediada pela norepinefrina e resposta relaxante mediada pela acetilcolina dimuídas. Drogas que melhoram a perda óssea que ocorre em conseqüência da doença melhoram e/ou restauram a resposta destes vasos. As enzimas eNOS e iNOS participam da diminuição da resposta contrátil enquanto a isoforma COX-2 participa da diminuição da resposta relaxante.

Podemos assim propor um novo mecanismo através do qual a periodontite está relacionada a diversas disfunções cardiovasculares. 


\section{REFERÊNCIAS*}

AKALIN, F. A.; BALTACIOGLU, E.; ALVER, A.; KARABULUT, E. Lipid peroxidation levels and total oxidant status in serum, saliva and gingival crevicular fluid in patients with chronic periodontitis. J. Clin. Periodontol., v. 34, n. 6, p. 558-565, 2007.

ALBANDAR, J. M. Periodontal diseases in North America. Periodontology 2000, v. 29, n. 1, p. 31-69, 2002.

ALMENDINGEN, K.; LARSEN, L. N.; FAUSA, O.; BRATLIE, J.; HøSTMARK, A. T.; AABAKKEN, L. Selective COX-2 inhibition affects fatty acids, but not COX mRNA expression in patients with FAP. Fam. Cancer., v. 9, n. 4, p. 571-580, 2010.

ALTMAN, L. C.; BAKER, C.; FLECKMAN, P.; LUCHTEL, D.; ODA, D.Neutrophilmediated damage to human gingival epithelial cells. J. Periodontal Res., v. 27, n. 1, p. 70-79, 1992.

AMAR, S.; GOKCE, N.; MORGAN, S.; LOUKIDELI, M.; VAN DYKE, T. E.; VITA, J. A. Periodontal disease is associated with brachial artery endothelial dysfunction and systemic inflammation. Arterioscler. Thromb. Vasc. Biol., v. 23, n. 7, p. 1245-1249, 2003.

AMIRI, F.; VIRDIS, A.; NEVES, M. F.; IGLARZ, M.; SEIDAH, N. G.; TOUYZ, R. M.; REUDELHUBER, T. L.; SCHIFFRIN, E. L. Endothelium-restricted overexpression of human endothelin-1 causes vascular remodeling and endothelial dysfunction. Circulation, v. 110, n. 15, p. 2233-2240, 2004.

BARBEIRO, H. V.; BARBEIRO, D. F.; DEBBAS, V.; SOUZA, H. P.; LAURINDO, F. R.; VELASCO, I. T.; SORIANO, F. G. Purine nucleotides reduce superoxide production by nitric oxide synthase in a murine sepsis model. Braz. J .Med. Biol. Res., v. 42, n. 11, p. 1050-1057, 2009.

BECK, J.; GARCIA, R.; HEISS, G.; VOKONAS, P. S.; OFFENBACHER S. Periodontal disease and cardiovascular disease. J. Periodontol., v. 67, n. 10, p. 1123-1137, 1996.

BENDALL, J. K.; ALP, N. J.; WARRICK, N.; CAI, S.; ADLAM, D.; ROCKETT, K.; YOKOYAMA, M.; KAWASHIMA, S.; CHANNON, K. M. Stoichiometric relationships between endothelial tetrahydrobiopterin, endothelial NO synthase (eNOS) activity, and eNOS coupling in vivo: insights from transgenic mice with endothelial-targeted GTP cyclohydrolase 1 and eNOS overexpression. Circ. Res., v. 97, n. 9, p. 864-871, 2005.

BEZERRA, M. M.; DE LIMA, V.; ALENCAR, V. B.; VIEIRA, I. B.; BRITO, G. A.; RIBEIRO, R. A.; ROCHA, F. A. Selective cyclooxygenase-2 inhibition prevents

\footnotetext{
* De acordo com:

ASSOCIAÇÃO BRASILEIRA DE NORMAS TÉCNICAS. NBR 6023: informação e documentação: referências: elaboração. Rio de Janeiro, 2002.
} 
alveolar bone loss in experimental periodontitis in rats. J. Periodontol., v. 71, n. 6, p. 1009-1014, 2000.

BEZERRA, M. M.; BRITO, G. A.; RIBEIRO, R. A.; ROCHA, F. A. Low-dose doxycycline prevents inflammatory bone resorption in rats. Braz. J. Med. Biol. Res., v. 35, n.5, p. $613-616,2002$.

BONFANTI, R.; FURIE, B. C.; FURIE, B.; WAGNER, D. D. PADGEM (GMP140) is a component of Weibel-Palade bodies of human endothelial cells. Blood, v. 73, n. 5, p. 1109-1112, 1989.

BOSSHARDT, D. D.; LANG, N. P. The junctional epithelium: from health to disease. J. Dent. Res., v. 84, n. 1, p. 9-20, 2005.

BOYCE, B. F.; AUFDEMORTE, T. B.; GARRETT, I. R.; YATES, A. J.; MUNDY, G. R. Effects of interleukin-1 on bone turnover in normal mice. Endocrinology, v. 125, n. 3, p. 1142-1150, 1989.

BOYLE, W. J.; SIMONET, W. S.; LACEY, D. L. Osteoclast differentiation and activation. Nature, v. 423, n. 6937, p. 337-342, 2003.

BUCHER, M.; KEES, F.; TAEGER, K.; KURTZ, A. Cytokines down-regulate alpha1adrenergic receptor expression during endotoxemia. Crit. Care Med., v. 31, n. 6, p. 566-571, 2003.

BUSSE, R.; FLEMING, I. Vascular endothelium and blood flow. Handb. Exp. Physiol., v. 176, n. 2, p. 43-78, 2006.

CHAN, P. S.; CERVONI, P.; ACCOMANDO, R. C.; QUIRK, G. J.; RONSBERG, M. A. Mechanism of action of a new prostaglandin antihypertensive, viprostol [CL 115347 ; (dl)-15-deoxy-16-hydroxy-16(alpha/beta)-vinyl-prostaglandin E2 methyl ester]: (II). Effects on the adrenergic nervous system. J. Hypertens., v. 4, n. 6, p. 749-757, 1986.

CHAN, C. C.; REID, C. M.; AW, T. J.; LIEW, D.; HAAS, S. J.; KRUM, H. Do COX-2 inhibitors raise blood pressure more than nonselective NSAIDs and placebo? An updated meta-analysis. J. Hypertens., v. 27, n.12, p. 2332-2341, 2009.

CHAPPLE, I. L.; MATTHEWS, J. B. The role of reactive oxygen and antioxidant species in periodontal tissue destruction. Periodontology 2000 , v. 43, n. 3, p. $160-$ $232,2007$.

D'AIUTO, F.; NIBALI, L.; PARKAR, M.; PATEL, K.; SUVAN, J.; DONOS, N. Oxidative stress, systemic inflammation, and severe periodontitis. J. Dent. Res., v. 89, n. 11, p. 1241-1246, 2010.

DE CATERINA, R.; LIBBY, P.; PENG, H. B.; THANNICKAL, V. J.; RAJAVASHISTH, T. B.; GIMBRONE JR, M. A.; SHIN, W. S.; LIAO, J. K. Nitric oxide decreases cytokineinduced endothelial activation. Nitric oxide selectively reduces endothelial 
expression of adhesion molecules and proinflammatory Cytokines. J. Clin. Invest., v. 96, n. 1, p. $60-68,1995$.

DELIMA, A. J.; KARATZAS, S.; AMAR, S.; GRAVES, D. T. Inflammation and tissue loss caused by periodontal pathogens is reduced by interleukin-1 antagonists. J. Infect. Dis., v. 186, n.4, p. 511-516, 2002.

DIXON, D. A.; KAPLAN, C. D.; MCINTYRE, T. M.; ZIMMERMAN, G. A.; PRESCOTT, S. M. Post-transcriptional control of cyclooxygenase-2 gene expression. The role of the 3'-untranslated region. J. Biol. Chem., v. 275, n. 16, p. 11750-11757, 2000.

DOCHERTY, J. R. Subtypes of functional alpha1-adrenoceptor. Cell Mol. Life Sci., v. 67, n.3, p. $405-417,2010$.

DUMONT, I.; PERI, K. G.; HARDY, P.; HOU, X.; MARTINEZ-BERMUDEZ, A. K.; MOLOTCHNIKOFF, S.; VARMA, D. R.; CHEMTOB, S. PGE2, via EP3 receptors, regulates brain nitric oxide synthase in the perinatal period. Am. J. Physiol., v. 275, n. 6, p.1812-1821, 1998.

DÜNSER, M. W.; HASIBEDER, W. R. Sympathetic overstimulation during critical illness: adverse effects of adrenergic stress. J. Intensive Care Med., v. 24, n. 5, p. 293-316, 2009.

FAUNCE, T.; TOWNSEND, R.; MCEWAN, A. The Vioxx pharmaceutical scandal: Peterson v Merke Sharpe ; Dohme (Aust) Pty Ltd (2010) 184 FCR 1. J. Law Med., v. 18, p. 38-49, 2010.

GARLET, G. P.; CARDOSO, C. R.; SILVA, T. A.; FERREIRA, B. R.; AVILACAMPOS, M. J.; CUNHA, F. Q.; SILVA, J. S. Cytokine pattern determines the progression of experimental periodontal disease induced by Actinobacillus actinomycetemcomitans through the modulation of MMPs, RANKL, and their physiological inhibitors. Oral Microbiol. Immunol., v. 21, p. 12-20, 2006.

GASPERSIC, R.; STIBLAR-MARTINCIC, D.; OSREDKAR, J.; SKALERIC, U. Influence of subcutaneous administration of recombinant TNF-alpha on ligatureinduced periodontitis in rats. J. Periodontal Res., v. 38, p. 198-203, 2003.

GARVEY, E. P.; OPLINGER, J. A.; FURFINE, E. S.; KIFF, R. J.; LASZLO, F.; WHITTLE, B. J.; KNOWLES, R. G. $1400 \mathrm{~W}$ is a slow, tight binding, and highly selective inhibitor of inducible nitric-oxide synthase in vitro and in vivo. J. Biol. Chem., v. 272, n. 8, p. 4959-4963, 1997.

GODFREY, V.; MARTIN, A. L.; STRUTHERS, A. D.; LYLES, G. A. Effects of aldosterone and related steroids on LPS-induced increased expression of inducible NOS in rat aortic smooth muscle cells. Br. J. Pharmacol., v. 164, n. 8, p. 2003-2014, 2011.

GYURKO, R.; BOUSTANY, G.; HUANG, P. L.; KANTARCI, A.; VAN DYKE, T. E.; GENCO C. A., GIBSON, F. C. Mice lacking inducible nitric oxide synthase 
demonstrate impaired killing of Porphyromonas gingivalis. Infect. Immun., v. 71, n. 9, p. 4917-4924, 2003.

GUYTON, A. C.; HALL, J. E. The autonomic nervous system: and the adrenal medulla. In: Saunders; 2000 . p. 697-708.

Textbook of Medical Physiology. Philadelphia, PA: W.B.

GRAVES, D. T.; COCHRAN, D. The contribution of interleukin-1 and tumor necrosis factor to periodontal tissue destruction. J. Periodontol., v. 74, p. 391-401, 2003.

GYÖRFI, A.; FAZEKAS, A.; SUBA, Z.; ENDER, F.; ROSIVALL. L. Neurogenic component in ligature-induced periodontitis in the rat. J. Clin. Periodontol., v. 21, p. 601-605, 1994.

HAFFAJEE, A. D.; SOCRANSKY, S. S. Attachment level changes in destructive periodontal diseases. J. Clin. Periodontol., v. 13, p. 461-472, 1986.

HANSSON, G. K.; LIBBY, P. The immune response in atherosclerosis: a doubleedged sword. Nature Rev. Immunol., v. 6, p. 508-519, 2006.

HERNANZ, R.; ALONSO, M. J.; BRIONES, A. M.; VILA, E.; SIMONSEN, U.; SALAICES, M. Mechanisms involved in the early increase of serotonin contraction evoked by endotoxin in rat middle cerebral arteries. Br. J. Pharmacol., v. 140, p. 671-680, 2003.

HERRERA, B. S.; MARTINS-PORTO, R.; CAMPI, P.; HOLZHAUSEN, M.; TEIXEIRA, S. A.; MENDES, G. D.; COSTA, S. K.; GYURKO, R.; VAN DYKE, T. E.; SPOLIDÓRIO, L. C.; MUSCARÁ, M. N. Local and cardiorenal effects of periodontitis in nitric oxide-deficient hypertensive rats. Arch. Oral Biol., v. 56, p. 41-47, 2011.

HERZBERG, M. C.; MACFARLANE, G. D.; GONG, K.; ARMSTRONG, N. N.; WITT, A. R.; ERICKSON, P. R.; MEYER, M. W. The platelet interactivity phenotype of Streptococcus sanguis influences the course of experimental endocarditis. Infect. Immun., v. 60, p. 4809-4818, 1992.

HIGASHI, Y.; GOTO, C.; HIDAKA, T.; SOGA, J.; NAKAMURA, S.; FUJII, Y.; HATA, T.; IDEI, N.; FUJIMURA, N.; CHAYAMA, K.; KIHARA, Y.; TAGUCHI, A. Oral infection-inflammatory pathway, periodontitis, is a risk factor for endothelial dysfunction in patients with coronary artery disease. Atherosclerosis, v. 206, p. 604610, 2009.

HOFBAUER, L. C.; HEUFELDER, A. E. Role of receptor activator of nuclear factorkappaB ligand and osteoprotegerin in bone cell biology. J. Mol. Med., v. 79, p. 243253, 2001.

HOLZHAUSEN, M.; SPOLIDORIO, D. M.; MUSCARÁ, M. N.; HEBLING, J.; SPOLIDORIO, L. C. Protective effects of etoricoxib, a selective inhibitor of cyclooxygenase-2, in experimental periodontitis in rats. J. Periodontal. Res., v. 40, n. 3, p. 208-211, 2005. 
KATUSIĆ, Z. S.; SHEPHERD, J. T. Endothelium-derived vasoactive factors: II. Endothelium-dependent contraction. Hypertension, v. 18, p. 86-92, 1991.

KENDALL, H. K.; HAASE, H. R.; LI, H.; XIAO, Y.; BARTOLD, P. M. Nitric oxide synthase type-II is synthesized by human gingival tissue and cultured human gingival fibroblasts. Periodontal Res., v. 35, n. 4, p. 194-200, 2000.

KENWORTHY, R.; BAVEREL, M. Studies of a periodontal tissue lesion in the rat, untreated or treated with chlorhexidine digluconate. J. Clin. Periodontol., v. 8, n.4, p. 349-358, 1981.

KNOWLES, R. G.; MONCADA, S. Nitric oxide synthases in mammals. Biochem. J., v. 298, n. 2, p. 249-258, 1994.

KOIDE, M.; SUDA, S.; SAITOH, S.; OFUJI, Y.; SUZUKI, T.; YOSHIE, H.; TAKAI, M.; ONO, Y.; TANIGUCHI, Y.; HARA, K. In vivo administration of IL-1 beta accelerates silk ligature-induced alveolar bone resorption in rats. J. Oral Pathol. Med., v. 24, n. 4, p. 420-424, 1995.

LACEY, D. L.; TIMMS, E.; TAN, H. L.; KELLEY, M. J.; DUNSTAN, C. R.; BURGESS, T.; ELLIOTT, R.; COLOMBERO, A.; ELLIOTT, G.; SCULLY, S.; HSU, H.; SULLIVAN, J.; HAWKINS, N.; DAVY, E.; CAPPARELLI, C.; ELI, A.; QIAN, Y. X.; KAUFMAN, S.; SAROSI, I.; SHALHOUB, V.; SENALDI, G.; GUO, J.; DELANEY, J.; BOYLE, W. J. OSTEOPROTEGERIN ligand is a cytokine that regulates osteoclast differentiation and activation. Cell, v. 93, n. 2, p. 165-176, 1998.

LEONE, C. W.; BOKHADHOOR, H.; KUO, D.; DESTA, T.; YANG, J.; SIQUEIRA, M. F.; AMAR, S.; GRAVES, D. T. Immunization enhances inflammation and tissue destruction in response to Porphyromonas gingivalis. Infect. Immun., v .74, n. 4, p. 2286-2292, 2006.

LEY, K.; REUTERSHAN, J. Leucocyte-endothelial interactions in health and disease. Handb. Exp. Pharmacol., v. 176, n. 2, p. 97-133, 2006.

LOHINAI, Z.; BENEDEK, P.; FEHÉR, E.; GYÖRFI, A.; ROSIVALL, L.; FAZEKAS, A.; SALZMAN, A. L.; SZABÓ, C. Protective effects of mercaptoethylguanidine, a selective inhibitor of inducible nitric oxide synthase, in ligature-induced periodontitis in the rat. Br. J. Pharmacol., v. 123, n. 3, p. 353-360,1998.

LOOS, B. G. Systemic markers of inflammation in periodontitis. J. Periodontol., v. 6 , n. 5, p. 2106-2115, 2005.

MANDELL, R. L.; SOCRANSKY, S. S. A selective medium for Actinobacillus actinomycetemcomitans and the incidence of the organism in juvenile periodontitis. J. Periodontol., v. 52, n. 10, p. 593-598, 1981.

MARNETT, L. J.; ROWLINSON, S. W.; GOODWIN, D. C.; KALGUTKAR, A. S.; LANZO, C. A. Arachidonic acid oxygenation by COX-1 and COX-2. Mechanisms of catalysis and inhibition. J. Biol. Chem., v. 274, n. 33, p. 22903-22906, 1999. 
MATSUZAKI, K.; UDAGAWA, N.; TAKAHASHI, N.; YAMAGUCHI, K.; YASUDA, H.; SHIMA, N.; MORINAGA, T.; TOYAMA, Y.; YABE, Y.; HIGASHIO, K.; SUDA, T. Osteoclast differentiation factor (ODF) induces osteoclast-like cell formation in human peripheral blood mononuclear cell cultures. Biochem. Biophys. Res. Commun., v. 246, n. 1, p. 199-204, 1998.

MATTHEWS, J. B.; WRIGHT, H. J.; ROBERTS, A.; LING-MOUNTFORD, N.; COOPER, P. R.; CHAPPLE, I. L. Neutrophil hyper-responsiveness in periodontitis. J. Dent. Res., v. 86, n. 8, p. 718-722, 2007.

MCGIFF, J. C.; QUILLEY, J. 20-HETE and the kidney: resolution of old problems and new beginnings. Am. J. Physiol., v. 277, n. 3, p. 607-623, 1999.

MEDZHITOV, R. Origin and physiological roles of inflammation. Nature, v. 24, n. 7203, p. 428-435, 2008.

MINICK, C. R.; FABRICANT, C. G.; FABRICANT, J.; LITRENTA, M. M. Atheroarteriosclerosis induced by infection with a herpesvirus. Am. J. Pathol., v. 96, n. 3, p. 673-706, 1979.

MUSCARÁ, M. N.; MCKNIGHT, W.; DEL SOLDATO, P.; WALLACE, J. L. Effect of a nitric oxide-releasing naproxen derivative on hypertension and gastric damage induced by chronic nitric oxide inhibition in the rat. Life Sci., v.62, n. 15, p. 235-240, 1998.

NANCl, A.; BOSSHARDT, D. D. Structure of periodontal tissues in health and disease. Periodontology 2000, v. 40, n. 5, p. 11-28, 2006.

NAPIMOGA, M. H.; BENATTI, B. B.; LIMA, F. O.; ALVES, P. M.; CAMPOS, A. C.; PENA-DOS-SANTOS, D. R.; SEVERINO, F. P.; CUNHA, F. Q.; GUIMARÃES, F. S. Cannabidiol decreases bone resorption by inhibiting RANK/RANKL expression and pro-inflammatory cytokines during experimental periodontitis in rats. Int. Immunopharmacol., v. 9, n. 2, p. 216-222, 2009.

NEWMAN, H. N. Attrition, eruption, and the periodontium. J. Dent. Res., v. 78, n. 3, p. $730-734,1999$.

NOWOTNY, A.; SANAVI, F. Induction of nonspecific tolerance to endotoxins reduces the alveolar bone resorption in ligature-treated rats. Infect. Immun., v. 39, n. 2, p. 873-878, 1983.

PALSSON-MCDERMOTT, E. M.; O'NEILL, L. A. Signal transduction by the lipopolysaccharide receptor, Toll-like receptor-4. Immunology, v. 113, n. 2, p. 153162, 2004.

PASTER, B. J.; OLSEN, I.; AAS, J. A.; DEWHIRST, F. E. The breadth of bacterial diversity in the human periodontal pocket and other oral sites. Periodontology 2000, v. 42, n. 3, p. $80-87,2006$. 
PIHLSTROM, B. L.; MICHALOWICZ, B. S.; JOHNSON, N. W. Periodontal diseases. Lancet., v. 366, n. 9499, p. 1809-1820, 2005.

POBER, J. S.; COTRAN, R. S. The role of endothelial cells in inflammation. Transplantation, v. 50, n. 4, p. 537-544, 1990.

POBER, J. S.; SESSA, W. C. Evolving functions of endothelial cells in inflammation.Nat. Rev. Immunol., v. 7, n.10, p. 803-815, 2007.

RENVERT, S. Destructive periodontal disease in relation to diabetes mellitus, cardiovascular diseases, osteoporosis and respiratory diseases. Oral Health Prev. Dent., n. 1, p. 358-359, 2003. Suppl. 1.

RIBEIRO, M. O.; ANTUNES, E.; DE NUCCI, G.; LOVISOLO, S. M.; ZATZ, R. Chronic inhibition of nitric oxide synthesis. A new model of arterial hypertension. Hypertension, v. 20, n. 3, p. 298-303, 1992.

RIDKER, P. M.; HAUGHIE, P. Prospective studies of C-reactive protein as a risk factor for cardiovascular disease. J. Investig. Med., v. 46, n. 8, p. 391-395, 1998.

ROVIN, S.; COSTICH, E. R.; GORDON, H. A. The influence of bacteria and irritation in the initiation of periodontal disease in germfree and conventional rats. $J$. Periodontal Res., v. 1, n. 3, p. 193-204, 1966.

SAMEJIMA, Y.; EBISU, S.; OKADA, H. Effect of infection with Eikenella corrodens on the progression of ligature-induced periodontitis in rats. J. Periodontal Res., v. 25, n. 5, p. 308-315, 1990.

SCANNAPIECO, F. A.; PAPANDONATOS, G. D.; DUNFORD, R. G. Associations between oral conditions and respiratory disease in a national sample survey population. Ann. Periodontol., v. 3, n. 1, p. 251-256, 1998.

SCHMIDT, C.; KURT, B.; HÖCHERL, K.; BUCHER, M. Inhibition of NF-kappaB activity prevents downregulation of alpha1-adrenergic receptors and circulatory failure during CLP-induced sepsis. Shock, v. 32, n. 3, p. 239-246, 2009.

SESSA, W. C. eNOS at a glance. J. Cell Sci., v. 117, n. 12, p. 2427-2429, 2004.

SOCRANSKY, S. S.; HAFFAJEE, A. D. Evidence of bacterial etiology: a historical perspective. Periodontol 2000, v. 5, n. 2, p. 7-25, 1994.

SOCRANSKY, S. S.; HAFFAJEE, A. D. Dental biofilms: difficult therapeutic targets. Periodontology 2000, v. 28, n. 2, p. 12-55, 2002.

TANG, E. H.; VANHOUTTE, P. M. Prostanoids and reactive oxygen species: team players in endothelium-dependent contractions. Pharmacol. Ther., v. 122, n. 2, p. 140-149, 2009. 
TAUBMAN, M. A.; VALVERDE, P.; HAN, X.; KAWAI, T. Immune response: the key to bone resorption in periodontal disease. J. Periodontol., v. 76, n. 11, p. 2033-2041, 2005.

VANHOUTTE, P. M. Endothelium and control of vascular function. State of the Art lecture. Hypertension, v. 13, n. 2, p. 658-667, 1989.

WARNER, T. D.; MITCHELL, J. A. Cyclooxygenases: new forms, new inhibitors, and lessons from the clinic. FASEB J., v. 18, n. 7, p. 790-804, 2004.

WEINER, G. S.; DEMARCO, T. J.; BISSADA, N. F. Long term effect of systemic tetracycline administration on the severity of induced periodontitis in the rat. $J$. Periodontol., v. 50, n. 12, p. 619-623, 1979.

YAMAGUCHI, O.; KANESHIRO, T.; SAITOH, S.; ISHIBASHI, T.; MARUYAMA, Y.; TAKEISHI, Y. Regulation of coronary vascular tone via redox modulation in the alpha1-adrenergic-angiotensin-endothelin axis of the myocardium. Am. J. Physiol. Heart Circ. Physiol., v. 296, n. 1, p. 226-232, 2009.

ZUBERY, Y.; DUNSTAN, C. R.; STORY, B. M.; KESAVALU, L.; EBERSOLE, J. L.; HOLT, S. C.; BOYCE, B. F.Bone resorption caused by three periodontal pathogens in vivo in mice is mediated in part by prostaglandin. Infect. Immun., v. 66, n. 9, p. 4158-4162, 1998. 